University of Nebraska - Lincoln

DigitalCommons@University of Nebraska - Lincoln

Winter 11-19-2021

\title{
Survey of State Laws Governing Continuances and Stays in Eviction Proceedings
}

Ryan Sullivan

University of Nebraska-Lincoln, sullivan@unl.edu

Follow this and additional works at: https://digitalcommons.unl.edu/lawfacpub

Part of the Civil Law Commons, Civil Procedure Commons, Courts Commons, Housing Law

Commons, Litigation Commons, and the Property Law and Real Estate Commons

Sullivan, Ryan, "Survey of State Laws Governing Continuances and Stays in Eviction Proceedings" (2021). College of Law, Faculty Publications. 223.

https://digitalcommons.unl.edu/lawfacpub/223

This Article is brought to you for free and open access by the Law, College of at DigitalCommons@University of Nebraska - Lincoln. It has been accepted for inclusion in College of Law, Faculty Publications by an authorized administrator of DigitalCommons@University of Nebraska - Lincoln. 


\title{
SURVEY OF STATE LAWS GOVERNING CONTINUANCES AND STAYS IN EVICTION PROCEEDINGS
}

\author{
Ryan Sullivan ${ }^{1}$
}

A continuance ${ }^{2}$ of trial can be an important tool for ensuring just and lawful outcomes. For example, a continuance can give a party more time to conduct discovery, obtain legal representation, or ensure that a witness is available for trial. In an eviction setting, a continuance helps ensure the tenant has a reasonable opportunity to appear at the trial, as the trial date is often selected without input from the tenant; it is probable that the trial date selected by the landlord or the court will conflict with the tenant's work schedule or a medical appointment, or it occurs on a day when the tenant is out of town, ill, or does not have childcare.

To prevent a party from unduly delaying trial by abusing the continuance mechanism, courts are given discretion on granting a request for a continuance. When determining whether to grant the request, the court can consider the merits of the request, the merits of the underlying matter, and the number of continuances previously granted, if any. Under most states' general rules of civil procedure, a party need only show "good cause" for the continuance. ${ }^{3}$ States and courts will differ on what is required to show good cause, but good cause is typically viewed as a relatively low bar.

In an eviction matter, a trial continuance can be an essential tool for preventing improper or unlaw evictions. Under the laws of most states, tenants are initially given only a few days' notice of their trial, during which they must find an attorney and complete all the tasks necessary to prepare for trial. Understandably, there are some eviction matters where a continuance is unnecessary, such as when the tenant has no defense to the eviction or has already vacated the premises. In these circumstances, the imposition of strict limitations on continuing the trial are justified. However, in instances where the facts are contested or the eviction has been brought unlawfully, additional time may be necessary to limit the risk of the tenant being unlawfully removed from their home.

Despite this need, most states have enacted statutes limiting a tenant's access to a continuance in an eviction action. ${ }^{4}$ State statutes vary in how they restrict a tenant's access to a continuance, but each includes one or all of the following: 1) a burden for obtaining the

\footnotetext{
${ }^{1}$ Ryan Sullivan, Associate Professor of Law, University of Nebraska College of Law. Research assistance provided by law students Justin Bergeson and Ryley Thomas, and editing provided by Deanna Lubken.

${ }^{2} \mathrm{~A}$ continuance is a postponement of a hearing, trial or other proceeding; in some states, it is labeled an adjournment.

${ }^{3}$ Thirty-two states. Alaska, Arkansas, Arizona, California, Colorado, Connecticut, Florida, Hawaii, Illinois, Kansas, Louisiana ("good grounds"), Maine, Massachusetts, Michigan, Missouri, Mississippi, Montana, Nebraska, Nevada, New Mexico, North Carolina, North Dakota, Oregon, Pennsylvania, Rhode Island, South Carolina, South Dakota, Tennessee, Texas, Utah, Virginia, and Wyoming. Among states that do not specifically establish "good cause" as the standard, most have caselaw establishing this as the standard.

${ }^{4}$ Notably, the Uniform Residential Landlord and Tenant Act of 1972 (URLTA) does not contain a any specific pertaining to continuances of an eviction matter. UNIF. RESIDENTIAL LANDLORD \& TENANT ACT (UNIF. L. COMM'N 1972). Section 1.103 provides only that the law should be construed as consistent with other law unless displaced by its own provisions. The revised 2015 URLTA contains similar language. See REV. UnIF. Residential LANDLORD \& TENANT ACT $§ 110$ (UNIF. L. COMM’N 2015).
} 
continuance that is higher or more restrictive than the traditional "good cause" standard, 2) a requirement to deposit funds with the court to secure a continuance beyond the date of trial, or 3) a limit on the number of days for which the matter may be continued. Note that some states also appear to limit a landlord's free access to a continuance, but this is typically of no consequence because a tenant will rarely object to a landlord seeking a continuance of an eviction proceeding. In addition, even in those states where continuances are not specifically limited by that state's landlord-tenant laws, a continuance may nonetheless be prohibited by virtue of the expedited eviction process requiring the trial occur within a specific number of days following the filing of the action.

Many states also include other continuance-related provisions among their landlord-tenant laws. For example, many states specifically prescribe stays to allow an opportunity to appeal the judgment, and a handful permit a court to stay the proceedings upon a showing of hardship or exigent circumstances. At least two states appear to provide a statutory right to continuance to obtain an attorney, and several states' courts appear to have established or at least acknowledged this right. Finally, a handful of states permit a tenant to stay the matter indefinitely (or have it dismissed) upon payment of all amounts due prior to the entry or execution of the judgmentoften viewed as a "right to redeem." A non-exhaustive list of states with these continuance-related provisions will be included at the end of the survey. Following the below survey are the laws and rules of each state governing continuances in eviction proceedings.

\section{Standard for a Obtaining a Continuance}

In nearly half of the 30 states with a specific statute governing continuances of eviction proceedings, a tenant-defendant faces a higher standard for achieving a continuance than the landlord-plaintiff. ${ }^{5}$ The burdens and requirements for seeking a continuance in an eviction matter vary greatly among the states, and include: a) a reliance on the standard rule applied to all civil matters in the state, b) a "good cause" standard specifically described in the laws governing landlord-tenant matters, c) an "extraordinary cause" standard applied only to a tenant in an eviction case, d) standards applicable depending on the situation, and e) other miscellaneous requirements.

A. Same as rule applied in all civil matters: In 38 states, a motion for a continuance is governed, at least for purposes of the standard applied in ruling upon the request, by the broader rule governing requests for continuances applicable in all civil matters. ${ }^{6}$

B. Good cause: Eight states' landlord-tenant statutes specifically provide that a continuance may be granted for good cause shown. ${ }^{7}$

C. Extraordinary cause: Nebraska was the only state in the country that required the showing of extraordinary cause to obtain a continuance in an eviction action. Nebraska recently amended its statute to permit one continuance for good cause, but for any

\footnotetext{
${ }^{5}$ California, Idaho, Minnesota, Montana, Nevada, Ohio, Oregon, Rhode Island, South Dakota, Virginia, West Virginia, and Wyoming.

${ }^{6}$ Alabama, Arkansas, Colorado, Connecticut, Delaware, Florida, George, Hawaii, Idaho, Illinois, Indiana, Iowa, Kansas, Kentucky, Louisiana, Maryland, Massachusetts, Michigan, Minnesota, Mississippi, Missouri, New Hampshire, New Jersey, North Carolina, North Dakota, Ohio, Oklahoma, Oregon, Pennsylvania, South Carolina, South Dakota, Texas, Utah, Vermont, Virginia, Washington, Wisconsin, and Wyoming.

${ }^{7}$ Alaska, Arizona, California, Maine, Michigan, Nebraska, New Mexico, and Tennessee.
} 
subsequent continuance, extraordinary cause must be shown. Extraordinary cause is not defined in Nebraska's landlord-tenant statute, nor in caselaw.

\section{Situational continuances ${ }^{8}$}

1. California: Continuance may be granted on motion by the defendant if the plaintiff amends his or her complaint. The defendant must show good cause by affidavit. West's Ann. Cal. C.C.P. 1173.

2. Colorado: The court may continue the case until personal service on the defendant is achieved if the defendant has only been served by constructive service. C.R.S.A. 13-40-115.

3. Iowa: Grants a continuance to a defendant as a matter of right if the hearing is scheduled for less than three days after service. I.C.A. 648.5. However, Iowa statute prohibits continuances for the purpose of taking testimony in writing. I.C.A. 648.16.

4. Maryland: The court has discretion to continue the case for 6-10 days if either party fails to appear. MD Code, Real Property section 8-402 and 8-402.1.

5. Montana: The court may grant a continuance upon amendment of the complaint after trial begins, if the defendant upon affidavit shows good cause therefor. Mont. Code. Ann. § 70-27-204.

6. Nevada: The court may grant a continuance upon amendment of the complaint after trial begins, if the defendant upon affidavit shows good cause therefor. Nev. Rev. Stat. Ann. § 40.330.

7. New Hampshire: The court may continue the action for one month if a defendanttenant asserts a statutory defense based on the landlord's failure to provide fit and habitable premises; the landlord may be given one month to attempt to remedy the violation. If remedied, the matter will be dismissed and the landlord will be awarded rents paid into the court; if not remedied, judgment will be entered in favor of the tenant, and the tenant will be refunded all rents paid into the court. N.H. Rev. Stat. 540:13-d.

8. Rhode Island: The court may continue the matter to permit the tenant to conduct discovery, for good cause shown, if the tenant files an answer and initiates discovery prior to the hearing. R.I. Gen. Laws 1956, 34-18-35.

\section{E. Other}

1. Colorado: If the continuance will be for longer than five days, the requesting party must again show good cause and pay a bond into the court, of an amount to be determined by the court based on how much the nonmoving party will be damaged. C.R.S.A. 13-40-114.

2. Minnesota: For any reason, the court has discretion to grant a continuance for no more than six days, but said continuance can go beyond six days only if all parties consent. If the eviction is for a reason other than nonpayment of rent, continuance

\footnotetext{
${ }^{8}$ California and Colorado have more than one rule specifically applying to different situations. In Iowa and Maryland, the state's default rule would still apply on a motion for a continuance.
} 
can be for no longer than three months and only if a material witness is not present (plus other factors). M.S.A. 504B.341.

3. Montana: Continuance may only be granted by party stipulation. If the parties stipulate, the tenant must pay undertaking with good and sufficient security to be approved by the court; must pay all damages and rent if judgment is against tenant. MCA 70-27-202.

4. Nebraska: If a subsequent continuance bleeds into a new rental period, the tenant may be required to pay rent into the court during the pendency of the proceeding. Neb. Rev. Stat. § 76-1443.

5. Nevada: In Nevada, each court may adopt its own rule on continuances. No matter the rule, a tenant must deposit rent to the court if judgment is delayed for any reason, including a continuance. N.R.S. 118A.490.

6. New York: The first request for a continuance is automatically granted and must be no less than 14 days. Any subsequent requests are subject to the discretion of the court. Notably, the statute permitting continuances only applies if triable issues of fact are raised. McKinney's RPAPL 745.

7. West Virginia: A continuance may be granted on a showing of cause. To obtain a continuance, a tenant must pay any periodic rent coming due during the continuance. W. Va. Code, 55-3A-3. For a landlord-plaintiff, a continuance may be granted at the discretion of the court. See Boyd v. Goffoli, 216 W.Va. 552, 608 S.E.2d 169 (W.Va. 2004). Handbook authority suggests that the movant must have some reason for the continuance. See Meyer, WVPRAC-TRH 3:1 (2020).

\section{Payment for a Continuance}

Twelve states require some form of payment to secure a continuance or to secure a continuance beyond a certain number of days in an eviction action. In eleven of these states, the requirement of payment applies only to the tenant-defendant. ${ }^{9}$ In Colorado, the payment requirement applies to the movant, regardless of whether the movant is a plaintiff or a defendant. Wyoming specifically requires a defendant in an eviction action to pay a bond for a continuance beyond two days, but also generally requires any movant to pay the costs of the continuance.

1. California: Initially, a continuance is governed by good cause under Cal. Rules of Court, Rule 3.1332. If the continuance is requested by the defendant and would push trial beyond 20 days after the request for time of trial, the court holds a hearing to determine if there is a reasonable probability the plaintiff will win. If so, the court determines the damages the plaintiff will suffer because of the continuance. The defendant pays into the court the amount determined. West's Ann. Cal. C.C.P. 1170.5 .

2. Colorado: Initially, a continuance may be granted on a showing of good cause under Colorado caselaw. See In re Marriage of Lorenzo, 721 P.2d 155 (1986). If the continuance will be for longer than five days, the requesting party must again

\footnotetext{
${ }^{9}$ California, Idaho, Montana, Nebraska, Nevada, Ohio, Oregon, South Dakota, Virginia, West Virginia, and Wyoming.
} 
show good cause and pay a bond into the court in an amount to be determined by the court based on how much the nonmoving party will be damaged. C.R.S.A. 1340-114.

3. Idaho: Initially, a continuance may be granted for good cause shown under I.R.C.P. Rule 2.2(b). If the continuance will be for longer than two days, the defendant must pay "a good and sufficient security" to the plaintiff. Payment may accrue if judgment is against a tenant. I.C. 6-311.

4. Montana: A continuance may be granted upon stipulation of the parties or payment by the defendant of a "good and sufficient security," the amount of which is to be approved by the court. The defendant must pay all damages and rent if judgment is against the defendant. MCA 70-27-202.

5. Nebraska: Each party may obtain one continuance for good cause shown, and any subsequent continuance requires a showing of extraordinary cause or agreement by the parties. If the subsequent continuance extends into the next rental period, the court may require the tenant-defendant pay rent into the court. Neb. Rev. Stat. $\S 76-1443$.

6. Nevada: A tenant must deposit rent to the court if judgment is delayed for any reason, including a continuance. Nev. Rev. Stat. 118A.490.

7. Ohio: For a continuance requested by a defendant that is for longer than eight days, the defendant must give a bond to the plaintiff "with good and sufficient surety." The amount of the bond must be approved by the court and is conditioned for accrued rent if judgment is against the defendant. If a plaintiff requests a continuance, the only requirement is that the plaintiff secure the consent of the defendant. R.C. 1923.08 .

8. Oregon: If a tenant-defendant requests a continuance that is to be longer than two days, the defendant must make an undertaking to the landlord "with good and sufficient surety." In certain actions, the defendant must pay rent as it comes due from commencement to entry of judgment. O.R.S. 105.140.

9. South Dakota: When seeking a continuance in an eviction action, the defendant must pay an undertaking with "good and sufficient surety" to the plaintiff of an amount to be approved by the court. S.D. Codified Law 21-16-7.

10. Virginia: If the tenant-defendant moves for a continuance, the landlord can request they pay into escrow the amount equal to what is due in rent. The tenant must make the escrow payment within a week. VA Code Ann. 55.1-1242.

11. West Virginia: To obtain a continuance, a tenant must pay any periodic rent coming due during the continuance. W. Va. Code, 55-3A-3.

12. Wyoming: Should a tenant in an eviction action apply for a continuance that is longer than for two days, the tenant must pay "bond with good and sufficient surety." W.S. 1977 1-21-1007.

\section{Time Limits or Other Form of Time Restriction}

Eighteen states restrict in some way a court's discretion when determining the duration of a continuance. Such restrictions come in a number of forms. Seven states require that a 
continuance be no longer than a specified number of days. Others, outlined above and in brief below, require either the defendant or the movant to pay a bond or other payment to the court or opposing party if the continuance exceeds a certain number of days. And, a few states have unique time-related provisions not susceptible to categorization.

A. Limit on Duration of Continuance

1. Arizona: Not more than three days in justice court or five days in superior court. A.R.S. 33-1377.

2. Minnesota: Not more than six days unless all parties consent. If eviction is for a reason other than nonpayment of rent, then continuance can be for no longer than three months, and only if a material witness is not present (plus other factors). M.S.A. 504B.341.

3. New Mexico: Up to seven days from the date of initial hearing. N.M.S.A. 47-843.

4. South Dakota: No more than 14 days. SDCL 21-16-7.

5. Tennessee: No more than 15 days unless agreement by the parties. T.C.A. 29-18118.

6. Texas: No more than seven days unless agreement by the parties. TX Rules of Civil Procedure, Rule 510.7.

7. Virginia: Court can grant the tenant a continuance of no more than one week to make a continuance escrow payment into the court. If paid, then no stated time limit for continuance, as long as the tenant continues to pay rent into the court. VA Code Ann. 55.1-1242.

B. Payment required when continuance is beyond a set number of days

1. Colorado: If the continuance will be for longer than five days, the requesting party must again show good cause and pay a bond into court, of an amount to be determined by the court based on how much the nonmoving party will be damaged. C.R.S.A. 13-40-114.

2. Ohio: For a continuance requested by a defendant that is for longer than eight days, the defendant must give a bond to the plaintiff "with good and sufficient surety." R.C. 1923.08 .

3. Oregon: If a tenant-defendant requests a continuance that is to be longer than two days, the defendant must make an undertaking to the landlord "with good and sufficient surety." In certain actions, the defendant must pay rent as it comes due from commencement to entry of judgment. O.R.S. 105.140.

4. Wyoming: Should a tenant in an eviction action apply for a continuance that is longer than for two days, the tenant must pay "bond with good and sufficient surety." W.S.1977 1-21-1007.

C. Unique provisions relating to time

1. California: If continuance pushes trial beyond two days of request for time of trial, then parties must agree to continuance, or the court holds a hearing to determine if 
there is a reasonable probability the plaintiff will win. If so, the court determines the damages the plaintiff will suffer because of the continuance. The defendant pays into the court the amount determined. West's Ann. Cal. C.C.P. 1170.5.

2. Mississippi: Single adjournment not to exceed 10 days, unless by consent. No adjournment in an eviction hearing shall extend the hearing beyond 45 days from the date of filing of the action. Miss. Code Ann. 89-7-39.

3. Montana: Continuance may only be granted by party stipulation. If the parties stipulate, the defendant must pay undertaking with good and sufficient security to be approved by the court, must pay all damages and rent if judgment is against tenant. MCA 70-27-202.

4. Nebraska: If a subsequent continuance extends into the next rental period, the court may require the tenant-defendant pay rent into the court. Neb. Rev. Stat. 76-1443.

5. New Hampshire: The landlord-plaintiff is permitted a continuance to provide time to remedy violation of health and safety standard if the tenant properly raises such violations as a defense to the eviction. N.H. Rev. Stat. 540:13-d.

6. New York: Continuance statute applies only if issues of fact are raised. The first request for a continuance is automatically granted, and must be no less than 14 days. McKinney's RPAPL 745.

7. North Carolina: Continuance may be granted for a period of time if a party initiates discovery or files motion to allow further pleadings or for summary judgment. N.C.G.S.A. 42-34.

\section{$\underline{\text { Other Continuance-Related Provisions }}$}

\section{Stay Pending Appeal}

A few states also specifically provide in their landlord-tenant laws specific provisions for post-judgment stays for the purpose of challenging the judgment for possession. It is presumed that in most states not listed below, a judgment for restitution may be stayed in the same manner as any other civil judgment, but this was not researched or verified.

1. Alabama: Writ may be stayed upon payment of all rents accrued since the date of the filing of the action and that accrue during the pendency of the appeal. Ala. Code $\S 6-6-351$.

2. Arkansas: Eviction may be stayed upon payment of an appeal bond within five days after service of a notice of appeal, and further sign an undertaking that the tenant will pay the landlord rent as it becomes due periodically after judgment was entered. Ark. Code Ann. § 18-17-910; Ark. Code Ann. § 18-17-707.

3. California: Providing a stay on appeal if a county court judge finds the tenant would suffer extreme hardship if no stay is given. Cal. Civ. Proc. Code $\S 1176$.

4. Connecticut: All eviction judgments are automatically stayed for five days, and if an appeal is filed during that period, the matter may be stayed until the final determination if bond is paid. Conn. Gen. Stat. Ann. $\$ 47 a-35$. 
5. Florida: Stay permitted upon posting of bond. Fla. R. App. P. 9.310.

6. Idaho: Stay granted on appeal at the discretion of the court. Idaho Code Ann. § 6319.

7. Michigan: The filing of an appeal and payment of the bond or escrow will stay an eviction that has been issued but not executed. Mich. Ct. R. 4.201(N).

8. Missouri: Application by the defendant for trial de novo or an appeal will stay an execution if the defendant also provides bond. The bond must be given with sufficient security for the total cost of the judgment and additional fees. Mo. Stat. Ann. §535.110. If the defendant receives government rent reduction, then the bond may subsidize the amount of the rent reduction. Mo. Stat. Ann. $§ 534.580$.

9. Nebraska: If the defendant files an appeal and deposits the amount of the judgment and costs or gives an appeal bond with surety it shall stay the execution of any writ of restitution. Neb. Rev. Stat. 76-1447.

10. Nevada: Execution of judgment may be stayed upon the execution of an undertaking to pay a bond in an amount not less than twice the amount of judgment and costs. Nev. Rev. Stat. Ann. § J CTS RCP Rule 73A.

11. New Mexico: Appeal stays the execution of the writ of restitution if rent is paid during the pendency of appeal. N.M. Stat. Ann. § 47-8-47

12. North Carolina: An execution of a judgment for ejectment shall be stayed if the defendant-appellant pays any rent in arrears as determined by the magistrate. N.C. Gen. Stat. Ann. § 42-34.

13. Oklahoma: The defendant has two days post-judgment to file a supersedeas bond. This two-day limit may be extended at the discretion of the trial judge up to seven days. Okla. Stat. Ann. tit. 12, § 1148.10A.

14. Rhode Island: Automatic stay of five days to file appeal. 34 R.I. Gen. Laws $\S 34-$ 18-48. Thereafter, it appears the judgment would be stayed during the pendency of the appeal upon payment of rent as it comes due. 34 R.I. Gen. Laws $\S 34-18-47$; 34 R.I. Gen. Laws § 34-18-49.

15. Texas: May be granted a stay pending appeal by filing a Statement of Inability to Afford Payment of Court Costs, pay any amounts due in the notice issued, and paying rent as it accrues. Tex. R. Civ. P. 510.9.

16. Washington: May stay the judgment pending appeal by executing and filing a bond and paying all rents and damages accruing during the pendency of the appeal. Wash. Rev. Code Ann. § 59.12.200.

17. Wisconsin: The defendant may stay an appeal if they file within 15 days of the judgment and give a surety for the amount of the judgment. WSA 799.445.

\section{Stay Due to a Finding of Hardship}

At least a couple states provide for the stay of the writ or warrant directing the transfer of possession to the landlord upon a showing of exigent circumstances or substantial hardship.

1. Connecticut: Grants the court authority to stay the execution if the tenant is unable to secure suitable replacement housing. Conn. Gen. Stat. Ann. $97 \mathrm{a}-39$. 
2. Minnesota: If the court finds that there are extraordinary and exigent circumstances a writ may be stayed more than seven days. Minn. Stat. Ann. § 504B.345. Subdiv. 2.

3. Mississippi: If a judge finds good cause, a stay of three days may be issued. Miss. Code Ann. §89-7-45.

4. New Hampshire: A stay may be issued for up to three months so long as the tenant continues to make payments to the landlord and justice so requires. N.H. Rev. Stat. 540:13-c.

5. New Jersey: There are several laws in New Jersey that give tenants extra time due to hardship.

a. Extension for Moving Out. The tenant may seek up to seven days of additional time to move out, if they have a good reason. N.J. Ct. R. 6:6-6.

b. Extension if unable to find new housing. The court may grant an additional six months if the tenant can show they are unable to find new housing. N.J. Stat.2A:42-10.6.

c. Terminal Illness. If the tenant has lived in the residence for two years, is current on rent payments, and has a terminal illness, the court may issue a stay for up to 12 months. N.J. Stat. Ann. § 2A:18-59.1.

6. New York: Stay for up to one year upon a showing that the tenant cannot reasonably find suitable replacement housing. N.Y. Real Prop. Acts. Law $§ 753$.

7. North Dakota: Court may issue a stay, not longer than five days, if immediate restitution of the premises would place substantial hardship on the defendant or the defendant's family. N.D. Cent. Code Ann., § 47-32-04.

8. Wisconsin: The court may issue a stay upon determination of hardship for up to 30 days, if the tenant pays past due rent and ongoing rent. Wis. Stat. Ann. § 799.44.

\section{Opportunity to Obtain Legal Counsel}

At least two states appear to provide an opportunity for the matter to be continued or stayed to provide the tenant an opportunity to obtain legal counsel.

1. Iowa: If the hearing is held less than three days after the defendant received notice of the hearing, then the court shall notify the defendant they are entitled to a continuance to retain legal counsel. ICA 648.5.

2. Kansas: If the eviction matter is brought in small claims court, and upon request by either party, the court shall grant one reasonable continuance to allow a party to secure representation of an attorney. Kan. Stat. Ann. 61-2714.

In several of the states where the right to a continuance to retain counsel is not provided for statutorily, courts have considered the issue either directly or indirectly, and appear to favor a right to an opportunity to obtain legal assistance. See e.g., Taylor v. Gill St. Investments, 743 P.2d 345,349 (Alaska 1987) (the superior court twice continued the trial of this case to allow the tenant to obtain substitute counsel); Picasso Tower, Inc. v. Dairene Int'l, 874 So. 2d 640, 642 (Fla. Dist. Ct. App. 2004) (there had been an initial hearing one business day after entry of the injunction but 
the hearing was postponed to allow the tenant to obtain counsel); Nuruzzman v. Korotouov, 2018 Mass. App. Div. 110 (Dist. Ct. 2018) (finding the trial judge made a clear error of judgment that fell outside the range of reasonable alternatives when he responded to the tenant's repeated requests for a continuance to obtain counsel under all of these circumstances, and finding it was an abuse of discretion to deny the tenant's request for continuance in these circumstances); Branch Brook Gardens Tenants Ass'n v. Rent Leveling Bd. of Belleville, 177 N.J. Super. 1, 7, 424 A.2d 840, 842 (App. Div. 1980) (the matter was scheduled originally for January 16, 1979, but was postponed until February 8, 1979, apparently so that the tenants could obtain counsel); Carlton Associates v. Bayne, 2002, 191 Misc.2d 54, 740 N.Y.S.2d 785 (Civil Court of the City of New York had inherent power to adjourn nonpayment proceeding beyond 10-day period mandated by statute, for purpose of allowing the tenant to obtain counsel, since grant of continuance was an exercise of judicial discretion upon particular facts, with appropriate opportunity for counsel to be heard, and was exclusively a judicial act; court's discretion to control its calendar could not be circumscribed by the Legislature).

\section{Right of Redemption}

Some states have laws, in lieu of or in addition to a right to a continuance of the eviction proceeding, which permit an eviction matter to be stayed (and typically dismissed) if the rent is paid during the pendency of the action or otherwise paid before possession is restored to the landlord. These laws are often viewed as "rights of redemption."

1. Delaware: The tenant may stay all proceedings by paying rent due within 10 days of the judgment, if the default arose out of good faith dispute. Del. Code Ann. tit. $25 \S 5716$.

2. Hawaii: Proceedings are stayed if the tenant pays all rent due, interest of 8 cents per year, all costs and charges of proceedings, including the plaintiff's attorney fees before the writ issues. Haw. Rev. Stat. Ann $\S 666-14$.

3. Minnesota: If the tenant pays all due rent with interest and the landlord's attorney fees, not exceeding \$5, then the tenant may redeem tenancy. Minn. Stat. Ann. $\S 504 \mathrm{~B} .291(1)(\mathrm{a})$.

4. Mississippi: If the tenant's eviction is solely for nonpayment of rent and the tenant pays all rent due and late fees at or before the Magistrate issues the warrant, no warrant shall be issued. Miss. Code. Ann. $\S 89-7-45$.

5. Missouri: If the tenant pays all rent due and costs before the order of the court issues, the proceedings are stayed. Mo. Ann. Stat. $\S 535.160$.

6. New Jersey: The tenants shall have until the end of the court day to pay the rent due to dismiss the proceedings. See Cmty. Realty Mgmt., Inc. for Wrightstown Arms Apartments v. Harris, 155 N.J. 212, 714 A.2d 282 (1998); Hous. Auth. of Town of Morristown v. Little, 135 N.J. 274 (1994).

7. New York: Unless the right is waived by the lease, lessee may redeem the tenancy following default for nonpayment of rent if within one year after execution of the warrant, the lessee pays to the landlord or to the court all rent in arrears. N.Y. Real Prop. Acts. Law $\S 761$. 
8. Oklahoma: If the tenant fails to pay rent based on a good faith claim they have 72 hours to pay due rent and associated costs to stay a writ of execution. $12 \mathrm{Okl}$. St. Ann. 1148.10B.

9. Virginia: The tenant is allowed a redemption if they pay all due rent and fees by their trial date or at least 10 days after service of summons. Va. Code Ann. § 55.1$1250 \mathrm{~B}$.

10. Washington: The tenant or any party interested in continuance of tenancy may redeem the tenancy by paying into the court within five days after entry of judgment all rent due and any court costs not exceeding seventy-five dollars. Wash. Rev. Code Ann.§ 59.18.410.

11. Wisconsin: Eviction shall be stayed if the tenant applies for emergency assistance for families with needy children before the writ is issued. Wis. Stat. Ann. § 799.40. 


\section{Survey of State Laws Governing Continuances and Stays in Eviction Proceedings}

The following sets forth the provisions of each state's laws governing continuances and stays. As noted in the survey, in some states continuances of eviction proceedings are governed by the state's landlord-tenant laws or forcible entry and detainer statutes, while in other states continuances are simply governed by the standard rules of civil procedure applicable to all civil matters. Even in states with specific landlord-tenant laws governing continuances, those laws are often supplemented by the rules of civil procedure or case law. For example, a state's landlord-tenant law may provide that a continuance may not be granted for more than a certain number of days or unless a bond is paid, but the standard used for determining whether to grant the continuance, may be found in the state's rules of civil procedure or in case law interpreting those rules. The left column offers the location of the state's landlord-tenant and/or eviction laws, followed by the applicable provision(s) governing continuances. The right column sets forth each state's rules of civil procedure applicable to continuances, and any case law pertaining to continuances in landlord-tenant matters and as applied in other civil matters generally.

\begin{tabular}{|c|c|c|}
\hline & $\begin{array}{c}\text { Residential Landlord-Tenant Act or Related Act } \\
\text { Governing Eviction Proceedings }\end{array}$ & Rules of Civil Procedure or Case Law \\
\hline Alabama & $\begin{array}{l}\text { Alabama's landlord-tenant laws, found at } \S 35-9 \text { a-101 } \\
\text { et seq., do not contain any specific guidance on } \\
\text { continuances, but instead provide that eviction matters } \\
\text { shall be governed by the rules of civil procedure. } \\
\text { Ala. Code } \S 35-9 A-461 \text {. Landlord's action for } \\
\text { eviction, rent, monetary damages, or other relief. } \\
\text { (a) A landlord's action for eviction, rent, monetary } \\
\text { damages, or other relief relating to a tenancy } \\
\text { subject to this chapter shall be governed by } \\
\text { the Alabama Rules of Civil Procedure and } \\
\text { the Alabama Rules of Appellate Procedure } \\
\text { except as modified by this chapter. }\end{array}$ & $\begin{array}{l}\text { Alabama caselaw dictates that a continuance is "within the } \\
\text { sound discretion of the court." } \\
\text { State ex rel. Payne v. Empire Life Ins. Co., } 351 \text { So.2d } 538 \text { (Ala. } \\
\text { 1977). } \\
\text { "A trial court's denial of a motion for a continuance...will } \\
\text { generally be affirmed as exercise of the trial court's broad } \\
\text { discretion in such matters." } \\
\text { Peagler v. Skyline Shopping Ctr., } 662 \text { So. } 2 \mathrm{~d} 282,283 \text { (Ala. Civ. } \\
\text { App. 1995). }\end{array}$ \\
\hline Alaska & $\begin{array}{l}\text { Alaska's landlord-tenant laws, found at } \S 34.03 .010 \text { et } \\
\text { seq., provide that a continuance may be granted for } \\
\text { good cause shown. } \\
\text { Alaska Stat. } \S 34.03 .285 \text {. Service of process upon } \\
\text { tenant. } \\
\text { In an action for possession under this chapter, the } \\
\text { summons and complaint shall be served under the } \\
\text { provisions of Rule No. } 85 \text { of the Rules of Civil }\end{array}$ & $\begin{array}{l}\text { No continuance shall be granted for a longer period than } 2 \text { days, } \\
\text { unless the defendant applying therefor shall give an undertaking } \\
\text { to the adverse party, with sureties approved by the court, } \\
\text { conditioned to the payment of the rent that may accrue if } \\
\text { judgment is rendered against defendant. } \\
\text { Alaska R. Civ. P. } 85(\text { a)(3). } \\
\text { "...the party seeking a continuance must also show good cause. } \\
\text { The grant or denial of a continuance shall be overturned only if } \\
\text { the trial court abused its discretion. This court has found an }\end{array}$ \\
\hline
\end{tabular}




\begin{tabular}{|c|c|c|}
\hline & $\begin{array}{l}\text { Procedure. A continuance may not be granted } \\
\text { plaintiff or defendant except for good cause shown. }\end{array}$ & $\begin{array}{l}\text { abuse of discretion when the trial court's ruling either } \\
\text { substantially prejudices a party or denies the party a substantial } \\
\text { right." } \\
\text { Vinson v. Hamilton, } 854 \text { P.2d 733, } 735 \text { (Alaska 1993). } \\
\text { "The decision whether to grant a continuance ultimately rests in } \\
\text { the discretion of the trial court." } \\
\text { Taylor v. Gill St. Invs., } 743 \text { P.2d 345, } 349 \text { (Alaska 1987). }\end{array}$ \\
\hline Arizona & $\begin{array}{l}\text { Arizona's landlord-tenant laws, found at } \S 33-301 \text { et } \\
\text { seq., provide that a continuance may be granted for } \\
\text { good cause shown. } \\
\text { Ariz. Rev. Stat. Ann. } \S 33-1377 \text {. Special detainer } \\
\text { actions; service; trial postponement. } \\
\text { C. For good cause shown supported by an affidavit, } \\
\text { the trial may be postponed for not more than three } \\
\text { days in a justice court or five days in the superior } \\
\text { court. } \\
\text { Arizona Mobile Home Parks Residential Landlord and } \\
\text { Tenant Act } \\
\text { Ariz. Rev. Stat. Ann. tit. } 33 \text {, Ch. } 11 \text {, Refs \& Annos } \\
\text { A.R.S. } \S 33-1485 \text {. Special detainer actions; trial } \\
\text { postponement. } \\
\text { C. For good cause shown supported by an affidavit, } \\
\text { the trial may be postponed for not more than three } \\
\text { days in a justice court or five days in the superior } \\
\text { court. }\end{array}$ & $\begin{array}{l}\text { (1) Generally. If a court has set an action for trial on a specified } \\
\text { date, it may not postpone the trial unless: (A) good cause exists } \\
\text { to do so, supported by affidavit or other evidence; (B) the } \\
\text { parties' consent; or (C) postponement is required by operation of } \\
\text { law. Trial also may be postponed as authorized or required by } \\
\text { local rule. } \\
\text { Ariz. R. Civ. P. } 38.1 \text {. } \\
\text { "... a motion for continuance is addressed to the sound judicial } \\
\text { discretion of the trial court predicated on good cause." } \\
\text { Nordale v. Fisher, } 380 \text { P. } 2 \text { d } 1003 \text { (Ariz. 1963). }\end{array}$ \\
\hline Arkansas & $\begin{array}{l}\text { Arkansas statute provides for three methods of } \\
\text { eviction: Unlawful Detainer, Municipal Court } \\
\text { procedure, and Civil Eviction under the Arkansas } \\
\text { Residential Landlord Tenant Act of } 2007 \text {. It appears }\end{array}$ & $\begin{array}{l}\text { Ark. R. Civ. P., Rule 40. Trial Settings and Continuances } \\
\text { (b) Continuances. The court may, upon motion and for good } \\
\text { cause shown, continue any case previously set for trial. }\end{array}$ \\
\hline
\end{tabular}




\begin{tabular}{|c|c|c|}
\hline & $\begin{array}{l}\text { that none of these statutory schemes govern } \\
\text { continuances. } \\
\text { Ark. Code Ann. } \text { @ } 18-60-301 \text { et seq. Forcible Entry } \\
\text { and Detainer-Unlawful Detainer } \\
\text { Ark. Code Ann. § 18-60-304. Actions constituting } \\
\text { unlawful detainer. } \\
\text { Municipal Court Procedure: Ark. Code Ann. } \S 18-16 \text { - } \\
101 \text { (this method results in a misdemeanor if a tenant } \\
\text { does not pay rent on } 10 \text {-days' notice. Arkansas is the } \\
\text { only state that provides for criminal penalty on late } \\
\text { rent). } \\
\text { Ark. Code Ann. } § 18-17-101 \text { et seq. Arkansas } \\
\text { Residential Landlord-Tenant Act of } 2007 \text {. }\end{array}$ & \\
\hline California & $\begin{array}{l}\text { In California, the procedure for an unlawful detainer } \\
\text { (eviction) is governed by Cal. Civ. Proc. Code } \$ 1159 \\
\text { et seq. } \\
\text { Cal. Civ. Proc. Code } \S 1170.5 \text {. Time of trial; } \\
\text { extension; trial not within time; order of payment; } \\
\text { amount of damages } \\
\text { Comment: In general, an unlawful detainer lawsuit } \\
\text { must take place within the } 20 \text { th day that a request for } \\
\text { the time of trial is made. Under } 1170.5(\text { b), the court } \\
\text { may extend the } 20 \text {-day period for trial (1) on } \\
\text { agreement of all parties or (2) at the request of a party. } \\
\text { If a party requests extension, the court holds a hearing } \\
\text { to determine if there is a reasonable probability the } \\
\text { plaintiff will ultimately win the action. On finding of } \\
\text { that reasonable probability, the court determines the }\end{array}$ & $\begin{array}{l}\text { Cal. Rules of Court Rule } 3.1332 \text {. Motion or application for } \\
\text { continuance of trial } \\
\text { (c) Grounds for continuance } \\
\text { Although continuances of trials are disfavored, each request for } \\
\text { a continuance must be considered on its own merits. The court } \\
\text { may grant a continuance only on an affirmative showing of good } \\
\text { cause requiring the continuance. Circumstances that may } \\
\text { indicate good cause include: [see full statute for itemized list] } \\
\text { Outside of the rule above, postponements in California are } \\
\text { generally governed by West's Ann. Cal. Civ. Proc. Code } \S 588 \\
\text { et seq. Issues-the Mode of Trial and Postponements, } \\
\text { Cal. Civ. Proc. Code } \S 1179.01 \text { et seq. COVID-19 Tenant Relief } \\
\text { Act. }\end{array}$ \\
\hline
\end{tabular}




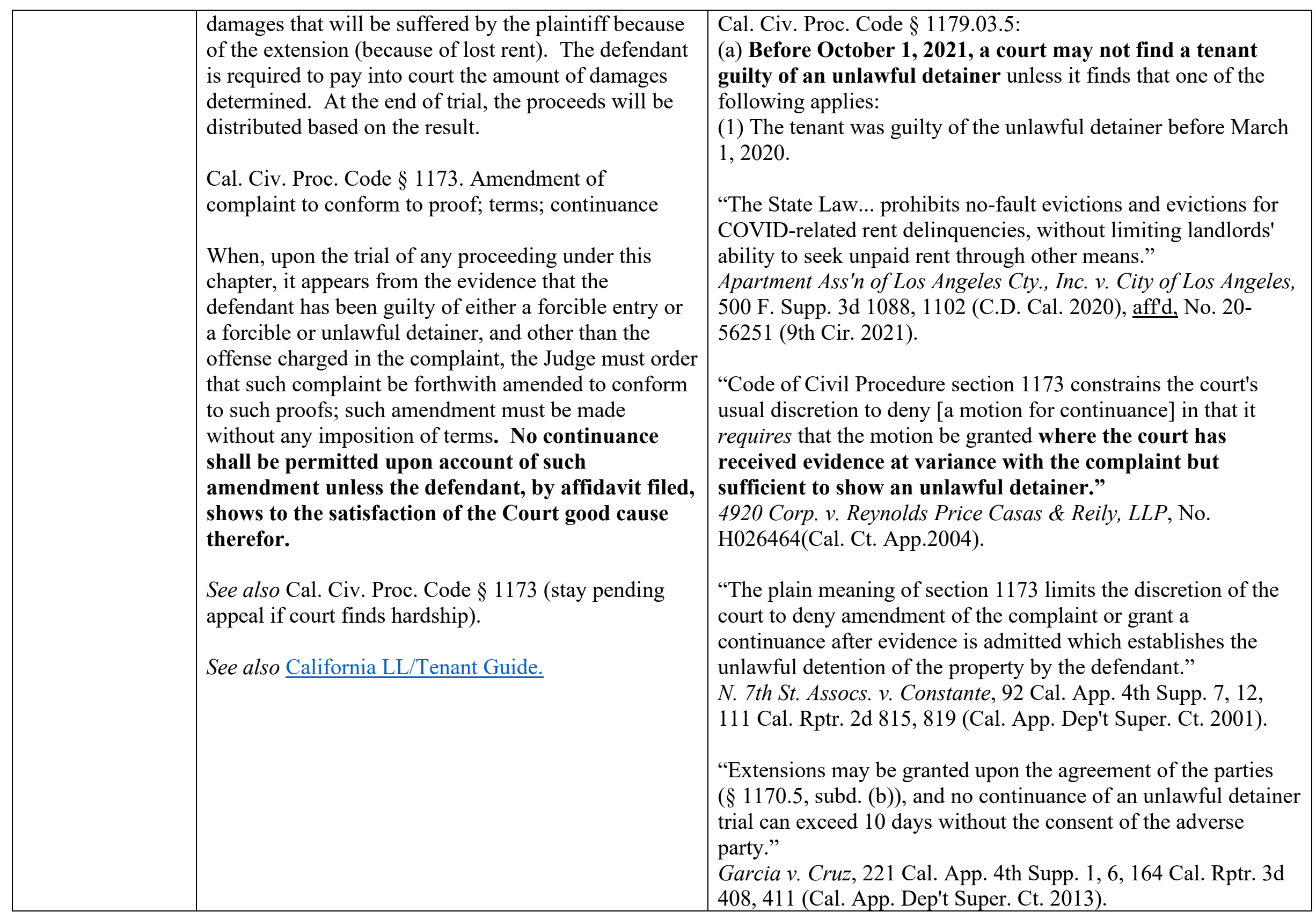




\begin{tabular}{|c|c|c|}
\hline Colorado & $\begin{array}{l}\text { Colorado's landlord-tenant laws, found at } \S 38-12-101 \\
\text { et seq., do not contain any specific guidance on } \\
\text { continuances. Colorado's Forcible Entry and Detainer } \\
\text { laws are found at } \S 13-40-101 \text {. } \\
\text { Colo. Rev. Stat. Ann. } \S 13-40-114 \text {. Delay in trial- } \\
\text { undertaking } \\
\text { If either party requests a delay in trial longer than five } \\
\text { days, the court in its discretion may, upon good cause } \\
\text { shown, require either of the parties to give bond or } \\
\text { other security approved and fixed by the court in an } \\
\text { amount for the payment to the opposite party of such } \\
\text { sum as he may be damaged due to the delay. } \\
\text { Colo. Rev. Stat. Ann. } \S 13-40-115 \text {. Judgment-writ of } \\
\text { restitution } \\
\text { (1) Upon the trial of any action under this article if } \\
\text { service was had only by posting in accordance with } \\
\text { section } 13-40-112(2) \text { and if the court finds that the } \\
\text { defendant has committed an unlawful detainer, the } \\
\text { court shall enter judgment for the plaintiff to have } \\
\text { restitution of the premises and shall issue a writ of } \\
\text { restitution. The court may also continue the case } \\
\text { for further hearing from time to time and may } \\
\text { issue alias and pluries summonses until personal } \\
\text { service upon the defendant is had. } \\
\text {-Effective only until Sept. } 30,2021 \text {. } \\
\text { See } 2 \text { A Colo. Prac., Methods of Practice } 71: 25 \text {. } \\
\text { See also Landlord/Tenant Guide. }\end{array}$ & $\begin{array}{l}\text { "Because the granting of a default judgment is a harsh remedy, } \\
\text { and because section } 13-40-114 \text { does not authorize such a } \\
\text { remedy for failure to post a bond, the trial court abused its } \\
\text { discretion in granting the default judgment." } \\
\text { Beeghly v. Mack, } 20 \text { P.3d } 610,614 \text { (Colo. 2001). } \\
\text { "In determining whether to grant a continuance, the court should } \\
\text { consider the circumstances of the particular case, weighing the } \\
\text { right of the party requesting the continuance to a fair hearing } \\
\text { against the prejudice that may result from delay." } \\
\text { Butler v. Farner, } 704 \text { P.2d } 853,858 \text { (Colo. 1985). }\end{array}$ \\
\hline
\end{tabular}




\begin{tabular}{|c|c|c|}
\hline Connecticut & $\begin{array}{l}\text { Connecticut's landlord-tenant laws, Conn. Gen. Stat. } \\
\text { Ann. } \S 47 \text { a-23 to } 47 \mathrm{a}-42 \mathrm{a} \text {, do not contain any specific } \\
\text { guidance on continuances. Presumably, a tenant could } \\
\text { move to continue under Conn. Gen. Stat. Ann. § 52- } \\
196 . \\
\text { However, Connecticut's URLTA provides for a } \\
\text { number of methods to obtain a stay the matter to } \\
\text { provide more time for the tenant to move out, when } \\
\text { the tenant is unable to find replacement housing, or to } \\
\text { file an appeal. See Conn. Gen. Stat. Ann.§ } 47 \text { a-37 } \\
\text { (providing a tenant an opportunity to stay execution of } \\
\text { the judgment if certain conditions are met); Conn. } \\
\text { Gen. Stat. Ann. } \$ 47 \text { a-39 (grants the court authority to } \\
\text { stay the execution if the tenant is unable to secure } \\
\text { suitable replacement housing); Conn. Gen. Stat. Ann. } \\
\S 47 \text { a-35 (providing that all eviction judgments shall } \\
\text { be automatically stayed for five days, and if an appeal } \\
\text { is filed during that period, the matter may be stayed } \\
\text { until the final determination if bond is paid). }\end{array}$ & $\begin{array}{l}\text { Conn. Gen. Stat. Ann. } § 52-196 \text {. Motion to continue or postpone } \\
\text { Whenever in any action pending in the Superior Court a motion } \\
\text { for a postponement or continuance is made by either party and } \\
\text { such motion is granted, the court may require the party making } \\
\text { the same to pay to the adverse party such sum by way of } \\
\text { indemnity as it deems reasonable. }\end{array}$ \\
\hline Delaware & $\begin{array}{l}\text { Delaware's landlord-tenant laws, } \S 5101 \text { et seq., do } \\
\text { not contain any specific guidance on continuances. } \\
\text { However, its laws permit a tenant to stay the } \\
\text { proceedings and redeem the tenancy if he or she pays } \\
\text { all due rent and the costs of a proceeding or files an } \\
\text { assurance that rent will be paid within } 10 \text { days: } \\
\text { Del. Code Ann. tit. } 25 \S 5716 \text {. Stay of proceedings by } \\
\text { tenant; good faith dispute } \\
\text { When a final judgment is rendered in favor of the } \\
\text { plaintiff in a proceeding brought against a tenant for } \\
\text { failure to pay rent and the default arose out of a good } \\
\text { faith dispute, the tenant may stay all proceedings on }\end{array}$ & $\begin{array}{l}\text { "The appellants owed back rent. They paid all of the back rent } \\
\text { and requested a stay. The Justices of Peace denied their stay } \\
\text { because there was not a good faith dispute." } \\
\text { Coverdale v. Just. of Peace Ct. of State In \& For Sussex Cty. No. } \\
\text { 1, No. CIV. A. 89M-DE1 (Del. Super. Ct. 1990). }\end{array}$ \\
\hline
\end{tabular}




\begin{tabular}{|c|c|c|}
\hline & $\begin{array}{l}\text { such judgment by paying all rent due at the date of the } \\
\text { judgment and the costs of the proceeding or by filing } \\
\text { with the court an undertaking to the plaintiff, with } \\
\text { such assurances as the court shall require, to the effect } \\
\text { that defendant will pay such rent and costs within } 10 \\
\text { days of the final judgment being rendered for the } \\
\text { plaintiff. At the expiration of said period, the court } \\
\text { shall issue a warrant of possession unless satisfactory } \\
\text { proof of payment is produced by the tenant. }\end{array}$ & \\
\hline Florida & $\begin{array}{l}\text { Florida's landlord-tenant laws, Fla. Stat. Ann. } \S 83.40 \\
\text { et seq., do not contain any specific guidance on } \\
\text { continuances. }\end{array}$ & $\begin{array}{l}\text { Fla. Stat. Ann. } § 1.460 \text {. Continuances } \\
\text { A motion for continuance shall be in writing unless made at a } \\
\text { trial and, except for good cause shown, shall be signed by the } \\
\text { party requesting the continuance. The motion shall state all of } \\
\text { the facts that the movant contends entitle the movant to a } \\
\text { continuance. If a continuance is sought on the ground of } \\
\text { nonavailability of a witness, the motion must show when it is } \\
\text { believed the witness will be available. }\end{array}$ \\
\hline Georgia & $\begin{array}{l}\text { Georgia's landlord-tenant laws, found at Ga. Code } \\
\text { Ann. } § 44-7-1 \text { et seq., do not contain any specific } \\
\text { guidance on continuances. }\end{array}$ & $\begin{array}{l}\text { Ga. Code Ann. } \S 9-10-167 \text {. Countershowing and discretion of } \\
\text { the court } \\
\text { (a) All applications for continuances are addressed to the sound } \\
\text { legal discretion of the court and, if not expressly provided for, } \\
\text { shall be granted or refused as the ends of justice may require. } \\
\text { (b) In all cases the presiding judge may, in his discretion, admit } \\
\text { a countershowing to a motion for a continuance and, after a } \\
\text { hearing, may decide whether the motion shall prevail. } \\
\text { "A denial of a motion for continuance is within the sound legal } \\
\text { discretion of the trial court and will not be disturbed absent } \\
\text { manifest abuse." Denny v. Croft, } 195 \text { Ga. App. } 871,395 \text { S.E.2d } \\
72,73 \text { (Ga. Ct. App. 1990). }\end{array}$ \\
\hline
\end{tabular}




\begin{tabular}{|c|c|c|}
\hline & & $\begin{array}{l}\text { “...[c]ontinuances because of the absence of counsel are not } \\
\text { favored..." } \\
\text { Cap. Floors, LLC v. Furman, } 351 \text { Ga. App. 589, 595, } 831 \text { S.E.2d } \\
\text { 522, } 528 \text { (Ga. Ct. App. 2019). } \\
\text { The court may consider prior continuances, counsel had not } \\
\text { notified the court of any issues or delays, and the schedules of } \\
\text { witnesses. } \\
\text { Mann v. State, } 307 \text { Ga. 696, 703, } 838 \text { S.E.2d 305, } 312 \text { (Ga. Ct. } \\
\text { App. 2020). } \\
\text { See also § 3:2.Continuances, Trial Handbook for Ga. Lawyers } \\
\S 3: 2 \text {. }\end{array}$ \\
\hline Hawaii & $\begin{array}{l}\text { Hawaii's landlord-tenant laws, found at Haw. Rev. } \\
\text { Stat. Ann. § } 521-1 \text {. Short title, et seq., does not contain } \\
\text { a specific provision on continuances. } \\
\text { However, Hawaii's statute governing eviction } \\
\text { proceedings does allow for a tenant to stay a writ of } \\
\text { possession after it has been issued and to redeem the } \\
\text { tenancy. } \\
\text { Haw. Rev. Stat. Ann. § 666-14. Writ stayed how, in } \\
\text { proceedings for nonpayment of rent } \\
\text { The issuing of the writ of possession shall be stayed } \\
\text { in the case of a proceeding for the nonpayment of } \\
\text { rent, if the person owing the rent, before the writ is } \\
\text { actually issued, pays the rent due and interest thereon } \\
\text { at the rate of eight per cent a year and all costs and } \\
\text { charges of the proceedings, and all expenses incurred } \\
\text { by plaintiff, including a reasonable fee for the } \\
\text { plaintiff's attorney. }\end{array}$ & $\begin{array}{l}\text { Haw. Cir. Ct. R. 7: Circuit Court Rule 7. Form of Motions: } \\
\text { (c) Required Notice; Effect of Failure to Appear. A party who } \\
\text { does not oppose or who intends to support a motion, or who } \\
\text { desires a continuance, shall immediately give written } \\
\text { notification to the court and opposing counsel. Failure to appear } \\
\text { at the hearing may be deemed a waiver of objections to the } \\
\text { granting of the motion. } \\
\text { (d) Motions for Continuance. If a date has been assigned for } \\
\text { trial of an action, a motion for continuance of the trial shall } \\
\text { include on the first page of the notice of motion the trial date } \\
\text { assigned and any previously assigned trial dates. } \\
\text { (e) Consent of Party to Continuance of Trial. A motion for } \\
\text { continuance of any assigned trial date, whether or not stipulated } \\
\text { to by respective counsel, shall be granted only upon a showing } \\
\text { of good cause, which shall include a showing that the client- } \\
\text { party has consented to the continuance. Consent may be } \\
\text { demonstrated by the client-party's signature on a motion for } \\
\text { continuance or by the personal appearance in court of the client- } \\
\text { party. }\end{array}$ \\
\hline
\end{tabular}




\begin{tabular}{|c|c|c|}
\hline & & $\begin{array}{l}\text { Haw. Dist. Ct. R. 7: District Court Rule 7. Form of Motions: } \\
\text { (c) Required Notice; Effect of Failure to Appear. A party who } \\
\text { does not oppose or who intends to support a motion, or who } \\
\text { desires a continuance, shall immediately notify the court and } \\
\text { opposing counsel, or opposing party if the opposing party is not } \\
\text { represented by counsel. Failure to appear at the hearing may be } \\
\text { deemed a waiver of objections to the granting of the motion. }\end{array}$ \\
\hline Idaho & $\begin{array}{l}\text { Idaho's Forcible Entry and Detainer laws, found at } \\
\S \text { 6-301 et seq., provide that a continuance may be } \\
\text { granted if the defendant gives good and sufficient } \\
\text { security. There are no explicit landlord-tenant } \\
\text { statutes. } \\
\text { Idaho Code Ann. § 6-311. Continuance } \\
\text { In an action exclusively for possession of a tract of } \\
\text { land of five (5) acres or less for the nonpayment of } \\
\text { rent or if a landlord has alleged that the landlord has } \\
\text { reasonable grounds to believe that any person, is or } \\
\text { has been, engaged in the unlawful delivery, } \\
\text { production, or use of a controlled substance during the } \\
\text { term for which the premises are let to the tenant, or if } \\
\text { the person is in possession of the property and is a } \\
\text { tenant at sufferance pursuant to subsection (11) of } \\
\text { section } 45-1506 \text {, Idaho Code, no continuance shall } \\
\text { be granted for a longer period than two (2) days } \\
\text { unless the defendant applying therefor gives an } \\
\text { undertaking to the adverse party with good and } \\
\text { sufficient security, to be approved by the court, } \\
\text { conditioned for the payment of the rent that may } \\
\text { accrue if judgment is rendered against the defendant. }\end{array}$ & $\begin{array}{l}\text { Idaho R. Civ. P. 2.5. Stipulations not binding on the court- } \\
\text { continuance of trial or hearing } \\
\text { The parties to any action may present to the court a stipulation as } \\
\text { to any procedural matter involved in any proceeding, including a } \\
\text { stipulation to vacate or continue a hearing or trial, but the } \\
\text { stipulation is to be considered as a joint motion by the parties to } \\
\text { the court for its consideration, and is not binding on the court. } \\
\text { The court may approve or disapprove the stipulation in the same } \\
\text { manner as the court rules on a motion. The court may by oral or } \\
\text { written notice to the parties limit the time within which a motion } \\
\text { or stipulation to vacate or continue a hearing or trial must be } \\
\text { made in order to be considered by the court. }\end{array}$ \\
\hline
\end{tabular}




\begin{tabular}{|c|c|c|}
\hline Illinois & $\begin{array}{l}\text { Illinois' landlord-tenant laws, found at } 765 \text { Ill. Comp. } \\
\text { Stat. Ann. } 705 / 0.01 \text { et seq., do not contain any specific } \\
\text { guidance on continuances. }\end{array}$ & $\begin{array}{l}735 \text { Ill. Comp. Stat. Ann. 5/2-1007. Extension of time and } \\
\text { continuances. On good cause shown, in the discretion of the } \\
\text { court and on just terms, additional time may be granted for the } \\
\text { doing of any act or the taking of any step or proceeding prior to } \\
\text { judgment.... } \\
\text { "We review the trial court's denial of a motion for a continuance } \\
\text { for abuse of discretion. A trial court abuses its discretion when } \\
\text { its decision is arbitrary, unreasonable, or fanciful or where no } \\
\text { reasonable person would take the view adopted by the court. } \\
\text { Under this standard, the reviewing court cannot substitute its } \\
\text { judgment for that of the trial court or determine whether the trial } \\
\text { court acted wisely." } \\
\text { Webster House Assocs. v. Baines, } 2021 \text { IL App (1st) 190273-U, } \\
\text { T 17. }\end{array}$ \\
\hline Indiana & $\begin{array}{l}\text { Indiana's landlord-tenant laws are found at Ind. Code } \\
\text { Ann. § 32-31-1-1 et seq., but the standard eviction } \\
\text { procedure is governed by its rules pertaining to Small } \\
\text { Claims actions found at Ind. Small Cl. R. } 1 \text { thru 16. et } \\
\text { seq. } \\
\text { Indiana's landlord and tenant laws also provide for an } \\
\text { "emergency proceeding for an emergency possessory } \\
\text { order." See Ind. Code Ann. § 32-31-6-1 et seq. This } \\
\text { process is available only for matters where the } \\
\text { landlord can claim "waste"-it is not available for } \\
\text { evictions for non-payment of rent, violation of the } \\
\text { lease agreement, or non-renewal. } \\
\text { Ind. Code Ann. § } 32-31-6-8 \\
\text { (c) The court shall not grant a continuance of the } \\
\text { emergency hearing except upon clear and convincing } \\
\text { evidence that manifest injustice would result if a } \\
\text { continuance were not granted. }\end{array}$ & $\begin{array}{l}\text { Ind. Small Cl. R. 9, Rule 9. Continuances } \\
\text { (A) Either party may be granted a continuance for good cause } \\
\text { shown. Except in unusual circumstances no party shall be } \\
\text { allowed more than one (1) continuance in any case, and all } \\
\text { continuances must have the specific approval of the court. } \\
\text { Continuances shall be for as short a period as possible, and } \\
\text { where feasible the party not requesting the continuance shall be } \\
\text { considered in scheduling a new hearing date. The court shall } \\
\text { give notice of the continuance and the new date and time of trial } \\
\text { to all parties. }\end{array}$ \\
\hline
\end{tabular}




\begin{tabular}{|c|c|c|}
\hline Iowa & $\begin{array}{l}\text { Iowa's landlord-tenant laws are found at } \S 562 \text { a. } 1 \text { et } \\
\text { seq., but the eviction process is governed by its } \\
\text { forcible entry and detainer statutes at } \S 648.1 \text { et seq., } \\
\text { which provides a right to a continuance if notice has } \\
\text { not been provided at least three days before trial. } \\
\text { Additional continuances are not specifically } \\
\text { prohibited, so presumably are governed by Iowa's } \\
\text { standard rules of civil procedure. } \\
\text { Iowa Code Ann. } \S 648.5 \text {. Venue-service of original } \\
\text { notice- hearing } \\
\text { 5. The notice requirements of this section shall be } \\
\text { deemed to have been satisfied if the defendant or the } \\
\text { defendant's attorney appears at the hearing. If the } \\
\text { hearing will be held fewer than three days after } \\
\text { service of the original notice or if notice is deemed } \\
\text { satisfied pursuant to this subsection, the court shall } \\
\text { inform the defendant that the defendant has the } \\
\text { right to a continuance and shall grant a } \\
\text { continuance at the defendant's request to allow the } \\
\text { defendant to prepare for the hearing or to retain an } \\
\text { attorney. } \\
\text { Iowa Code Ann. } \S 648.16 \text {. Priority of assignment } \\
\text { Such actions shall be accorded reasonable priority for } \\
\text { assignment to assure their prompt disposition. No } \\
\text { continuance shall be granted for the purpose of taking } \\
\text { testimony in writing. }\end{array}$ & $\begin{array}{l}\text { Iowa Code Ann. } \S 1.911 \text {. Causes for continuance } \\
\text { (1) A continuance may be allowed for any cause not growing out } \\
\text { of the fault or negligence of the movant, which satisfies the court } \\
\text { that substantial justice will be more nearly obtained. It shall be } \\
\text { allowed if all parties so agree and the court approves. } \\
\text { (2) All such motions based on absence of evidence must be } \\
\text { supported by affidavit of the party, the party's agent or attorney, } \\
\text { and must show the following: ... } \\
\text { Iowa Code Ann. } § 1.912 . \text { Objections; ruling; costs } \\
\text {...Every continuance shall be at the cost of the movant unless } \\
\text { otherwise ordered by the court. } \\
\text { "The Code provides that continuances shall not be granted for } \\
\text { any cause growing out of the fault or negligence of the party } \\
\text { applying therefor. Subject to this rule, however, continuances } \\
\text { may be allowed for any cause which satisfies the court that } \\
\text { substantial justice will thereby be more nearly attained." } \\
\text { Brady v. Malone, } 4 \text { Iowa } 146,148,149 \text { (Iowa } 1857 \text { ). } \\
\text { "The trial court is given guidelines to help exercise its discretion } \\
\text { when presented with a motion for continuance, which we in turn } \\
\text { use to measure the reasonableness of the trial court's } \\
\text { decision...." Thus, when a motion for continuance is promptly } \\
\text { filed, "alleging a cause not stemming from the movant's own } \\
\text { fault or negligence, the court must determine whether substantial } \\
\text { justice will be more nearly obtained by granting the request." } \\
\text { Ragan } v . \text { Petersen, } 569 \text { N.W. } 2 \mathrm{~d} 390,393 \text { (Iowa Ct. App. } 1997 \text { ) } \\
\text { (quoting State } v . \text { Birkestrand, } 239 \text { N.W.2d } 353,360 \text { (Iowa } \\
1976) \text { ). }\end{array}$ \\
\hline
\end{tabular}




\begin{tabular}{|c|c|c|}
\hline & & $\begin{array}{l}\text { "A motion for continuance addresses itself to the sound legal } \\
\text { discretion of the trial court, and his ruling will not be interfered } \\
\text { with on appeal unless the discretion has been abused and an } \\
\text { injustice done the party denied the continuance. This discretion } \\
\text { of the trial court is a judicial discretion to be governed and } \\
\text { controlled by legal rules and must be exercised, not capriciously } \\
\text { or oppressively, but for the prevention of injustice and } \\
\text { oppression." } \\
\text { Luse v. Waco Cmty. Sch. Dist. of Henry Cty., 258 Iowa 1087, } \\
\text { 1099,1100,141 N.W.2d 607, 615 (Iowa 1966). }\end{array}$ \\
\hline Kansas & $\begin{array}{l}\text { Kansas' landlord-tenant laws, found at } \S 58-2501 \text { et } \\
\text { seq., do not include any provisions regulating } \\
\text { continuances of an action for possession, but instead } \\
\text { specifically provide that the code of civil procedure } \\
\text { for limited action would apply. } \\
\text { Kan. Stat. Ann. §58-2542. Jurisdiction of courts; } \\
\text { procedure } \\
\text { The district court shall have jurisdiction over any } \\
\text { landlord or tenant with respect to any conduct in this } \\
\text { state governed by this act or with respect to any claim } \\
\text { arising from a transaction subject to this act, and } \\
\text { notwithstanding the provisions of subsection (b) of } \\
\text { Kan. Stat. Ann. } \S 61-2802 \text {, and amendments thereto, } \\
\text { such actions may be commenced pursuant to the code } \\
\text { of civil procedure for limited actions. Unless } \\
\text { otherwise specifically provided in this act, the code } \\
\text { of civil procedure for limited actions shall govern } \\
\text { any action commenced pursuant to this act. }\end{array}$ & $\begin{array}{l}\text { Kan. Stat. Ann. § 60-240. Scheduling for trial; continuances } \\
\text { (a) Scheduling cases for trial. Each district court must provide } \\
\text { by rule for scheduling trials. The court must give priority to } \\
\text { actions entitled to priority by law. } \\
\text { (b) Continuances. For good cause, the court may continue an } \\
\text { action at any stage of the proceedings on just terms. When a } \\
\text { continuance is granted due to the absence of evidence, it must be } \\
\text { at the cost of the party requesting the continuance, unless the } \\
\text { court orders otherwise. } \\
\text { (c) Motion for continuance based on absence of material } \\
\text { witness, document, thing or other evidence; affidavit or } \\
\text { declaration. (1) Affidavit or declaration in support of motions. } \\
\text { The court need not entertain a motion for a continuance based on } \\
\text { the absence of a material witness, document, thing or other } \\
\text { evidence unless supported by an affidavit or a declaration } \\
\text { pursuant to Kan. Stat. Ann. § } 53-601 \text {, and amendments thereto. } \\
\text { Kan. Stat. Ann. } \S 61-2714 \text {. Use of attorneys; certification by } \\
\text { plaintiff of compliance with act; defense related to limit on } \\
\text { number of claims } \\
\text { (b) When appropriate, the court shall advise all parties of this } \\
\text { right to hire counsel pursuant to this section and shall, if } \\
\text { requested by any party, grant one reasonable continuance in such }\end{array}$ \\
\hline
\end{tabular}




\begin{tabular}{|c|c|c|}
\hline & & $\begin{array}{l}\text { matter to afford a party an opportunity to secure representation } \\
\text { of an attorney. } \\
\text { The Small Claims Procedure Act may be utilized to resolve a } \\
\text { claim arising under the Residential Landlord and Tenant Act, so } \\
\text { long as the claim meets the statutory definition of a "small } \\
\text { claim" as provided in Kan. Stat. Ann. \& 61-2703. } \\
\text { Barton v. Miller, 225 Kan. 624, 625, 592 P.2d 921, } 923 \text { (Kan. } \\
\text { 1979). }\end{array}$ \\
\hline Kentucky & $\begin{array}{l}\text { Kentucky's landlord-tenant laws, found at } \S 383.010 \\
\text { et seq., do not include any provisions regulating } \\
\text { continuances of an action for possession. }\end{array}$ & $\begin{array}{l}\text { Ky. R. Crim. P. } 43.03 \text { Postponement of trial; motion and } \\
\text { affidavit } \\
\text { "...A motion to postpone a trial on account of the absence of } \\
\text { evidence may be made only upon affidavit showing the } \\
\text { materiality of the evidence expected to be obtained, and that due } \\
\text { diligence has been used to obtain it. If the motion is based on the } \\
\text { absence of a witness, the affidavit must show what facts the } \\
\text { affiant believes the witness will prove, and not merely the effect } \\
\text { of such facts in evidence, and that the affiant believes them to be } \\
\text { true. If the adverse party will consent that, on the trial, the } \\
\text { affidavit may be read as the deposition of the absent witness, the } \\
\text { trial shall not be postponed on account of his absence..." }\end{array}$ \\
\hline Louisiana & $\begin{array}{l}\text { La. Civ. Code Ann. art. } 2668 \text { et seq., comprises } \\
\text { Louisiana's landlord-tenant laws generally; the } \\
\text { eviction procedure is found at La. Civ. Code Ann. art. } \\
4701 \text { et seq. Neither provide any guidance on a } \\
\text { continuance of an action for possession. } \\
\text { In Louisiana, an eviction proceeding is initiated by } \\
\text { filing a "Rule for Possession." }\end{array}$ & $\begin{array}{l}\text { Louisiana statute provides for two kinds of continuances: } \\
\text { Peremptory continuances and discretionary continuances. } \\
\text { Peremptory continuances are governed by La. Civ. Code Ann. } \\
\text { art. } 1602 \text {. Discretionary continuances are governed by La. Civ. } \\
\text { Code Ann. art. } 1601 \text { and may be granted for "good grounds," } \\
\text { the definition of which is within the discretion of the court. } \\
\text { See New Hope Gardens, Ltd. v. Lattin, } 530 \text { So. } 2 \text { d } 1207,1212 \\
\text { (La. Ct. App. 1988) (describing } 1601 \text { and } 1602 \text { connections to } \\
\text { eviction proceedings). }\end{array}$ \\
\hline
\end{tabular}




\begin{tabular}{|c|c|c|}
\hline & & $\begin{array}{l}\text { See also Stoker v. Johnson, 96-28,168 (La. App. } 2 \text { Cir. 4/3/96), } \\
671 \text { So. 2d 1206, } 1207 \text { (court granted a continuance for } \\
\text { insufficiency of citation for eviction). }\end{array}$ \\
\hline Maine & $\begin{array}{l}\text { Maine's landlord-tenant laws are found at Me. Rev. } \\
\text { Stat. Ann. tit. 14, } \S 6021 \text { to } \S 6050 \text {, but its eviction } \\
\text { proceedings are governed by its entry and detainer } \\
\text { statutes found at } \S 6000 \text { to } \S 6017 \text {. } \\
\text { Me. Rev. Stat. Ann. tit. } 14 \S 6003 \text {. Jurisdiction } \\
\text { The District Court shall have jurisdiction of cases of } \\
\text { forcible entry and detainer. } \\
\text { The court shall schedule and hold the hearing as soon } \\
\text { as practicable, but no later than } 10 \text { days after the } \\
\text { return day except that the court may grant a } \\
\text { continuance for good cause shown. Any defendant } \\
\text { requesting a recorded hearing shall file a written } \\
\text { answer enumerating all known defenses on or before } \\
\text { the return day. }\end{array}$ & \\
\hline Maryland & $\begin{array}{l}\text { Maryland's landlord-tenant laws can be found at } \S 8- \\
101 \text { et seq., and provide that a continuance may be } \\
\text { granted at the discretion of the court. } \\
\text { Md. R. } \S \S 8-402 \text { and } 8-402.1 \text { give the court } \\
\text { discretionary authority to grant a continuance "not } \\
\text { less than } 6 \text { but no more than } 10 \text { days and notify the } \\
\text { parties of the continuance" if either of the parties } \\
\text { fails to appear before the court on the day stated in the } \\
\text { summons. }\end{array}$ & $\begin{array}{l}\text { Maryland statute allows a district court (Md. R. 3-508) and a } \\
\text { circuit court (Md. R. 2-508) to continue or postpone a trial or } \\
\text { other proceeding as "justice may require" on motion or on its } \\
\text { own initiative. }\end{array}$ \\
\hline
\end{tabular}




\begin{tabular}{|c|c|c|}
\hline Massachusetts & $\begin{array}{l}\text { Massachusetts' landlord-tenant laws are found at } \\
\text { Mass. Gen. Laws Ann. ch. } 186, \S \S 1 \text { to } 29 \text {; ch. 186a, } \\
\S \S 1 \text { to } 6 \text {, but its laws governing the eviction process } \\
\text { are found in court rule at Mass. Trial Ct. R. I: Uniform } \\
\text { Summary Process Rules. A Massachusetts' eviction } \\
\text { proceeding is called a summary process action. } \\
\text { Rule } 1 \text { of the Uniform Summary Process Rules states } \\
\text { that procedures not governed by these rules are } \\
\text { governed by the Massachusetts Rules of Civil } \\
\text { Procedure so long as the civil procedure rules are not } \\
\text { inconsistent with the Uniform Summary Process } \\
\text { Rules. Except as provided in the commentary for } \\
\text { Rule } 5 \text {, Massachusetts' laws pertaining to evictions } \\
\text { provide no guidance on continuances. } \\
\text { Commentary to Rule } 5 \text { of the Uniform Summary } \\
\text { Process Rules. Counterclaims of the Uniform } \\
\text { Summary Process Rules state that a court, in its } \\
\text { discretion, may grant a motion for a continuance in } \\
\text { order to grant a party time to prepare a defense to } \\
\text { a counterclaim. } \\
\text { See also Rule } 2 \text { of the Uniform Summary Process } \\
\text { Rules for the expedited timing of the summary } \\
\text { process. }\end{array}$ & $\begin{array}{l}\text { Mass. R. Civ. P., 40. Assignment of Cases for Trial: } \\
\text { Continuances } \\
\text { (b) Continuances. Continuances shall be granted only for good } \\
\text { cause, in accordance with general rules and orders which the } \\
\text { court may from time to time adopt. } \\
\text { "A judge should grant a continuance only when justice so } \\
\text { requires, balancing the requesting party's need for additional } \\
\text { time against concerns about inconvenience, cost, potential } \\
\text { prejudice, and the burden of the delay on both the parties and the } \\
\text { judicial system. A judge has committed an abuse of discretion } \\
\text { when the basis of the judge's decision stems from 'a clear error } \\
\text { of judgment in weighing' the factors relevant to the decision } \\
\text { and, thus, the decision falls outside the range of reasonable } \\
\text { alternatives." } \\
\text { Nuruzzman v. Korotouov, 2018 Mass. App. Div. 110, (Mass. } \\
\text { Dist. Ct. 2018) (citing cases) (quoting L.L. v. Commonwealth, } \\
470 \text { Mass. 169, 185 n.27 (Mass. 2014)). } \\
\text { Dolben Co. v. Friedmann, 2008 Mass. App. Div. 1, (Mass. Dist. } \\
\text { Ct. 2008) (suggesting that a defendant in a summary process } \\
\text { action may request a continuance). }\end{array}$ \\
\hline Michigan & $\begin{array}{l}\text { Michigan's landlord-tenant laws can be found at } \\
\text { Mich. Comp. Laws Ann. } \S 554.601 \text { to } 554.616 \text {. The } \\
\text { procedure for eviction is governed by a separate set of } \\
\text { statutes, Mich. Ct. R. } 4.201 \text { et seq., which provide } \\
\text { reference to the trial court's power to grant a } \\
\text { continuance. A separate court rule provides a } \\
\text { mechanism for staying the judgment pending appeal. }\end{array}$ & $\begin{array}{l}\text { Mich. Ct. R. } 2.503 \text { Adjournments } \\
\text { (B) Motion or Stipulation for Adjournment. } \\
\text { (1) Unless the court allows otherwise, a request for an } \\
\text { adjournment must be by motion or stipulation made in writing or } \\
\text { orally in open court and is based on good cause. }\end{array}$ \\
\hline
\end{tabular}




\begin{tabular}{|c|c|c|}
\hline & $\begin{array}{l}\text { Mich. Ct. R. 4.201. Summary Proceedings to Recover } \\
\text { Possession of Premises. } \\
\text { (J) Trial. } \\
\text { (1) Time. When the defendant appears, the court may } \\
\text { try the action, or, if good cause is shown, may } \\
\text { adjourn trial up to 56 days. If the court adjourns } \\
\text { trial for more than } 7 \text { days, an escrow order may be } \\
\text { entered pursuant to subrule (H)(2). The parties may } \\
\text { adjourn trial by stipulation in writing or on the record, } \\
\text { subject to the approval of the court. } \\
\text { ‥ } \\
\text { (M) Post judgment Motions. Except as provided in } \\
\text { MCR } 2.612 \text {, any post judgment motion must be filed } \\
\text { no later than } 10 \text { days after judgment enters. } \\
\text { (1) If the motion challenges a judgment for } \\
\text { possession, the court may not grant a stay unless } \\
\text { (a) the motion is accompanied by an escrow deposit of } \\
1 \text { month's rent, or } \\
\text { (b) the court is satisfied that there are grounds for } \\
\text { relief under MCR } 2.612(\mathrm{C}) \text {, and issues an order that } \\
\text { waives payment of the escrow; such an order may be } \\
\text { ex parte. } \\
\text { If a stay is granted, a hearing shall be held within } 14 \\
\text { days after it is issued. } \\
\text { There have been some changes to Mich. Ct. R. } 4.201 \\
\text { as a result of the COVID-19 pandemic. See Mich. } \\
\text { Admin. Code r. 2020-17. } \\
\text { See also Mich. Ct. R. } 4.201 \text { (N) (staying an eviction } \\
\text { during pendency of appeal). }\end{array}$ & $\begin{array}{l}\text { Mich. Comp. Laws Ann. } \S 600.5744 \text { does not require tenant to } \\
\text { file bond to stay proceedings within ten days after the judgment } \\
\text { for possession is entered to toll running of period during which } \\
\text { writ of restitution could not have been issued. } \\
\text { See Sun Valley Foods Co. v. Ward, } 460 \text { Mich. } 230,596 \text { N.W.2d } \\
119 \text { (Mich. 1999). }\end{array}$ \\
\hline
\end{tabular}




\begin{tabular}{|c|c|c|}
\hline Minnesota & $\begin{array}{l}\text { Minnesota's landlord-tenant laws can be found at } \\
\S 504 \mathrm{~B} .001 \text { et seq., and have several provisions } \\
\text { governing continuances and stays. } \\
\text { Minn. Stat. Ann. } \S 504 \mathrm{~B} .341 \text {. Continuance of trial } \\
\text { Under section (a), the court has discretion to grant a } \\
\text { continuance for no more than six days unless all } \\
\text { parties consent to longer continuance. } \\
\text { Section (b) applies to actions brought under } \\
\S 504 \mathrm{~B} .285 \text {, which governs eviction actions for } \\
\text { reasons other than nonpayment of rent. In this case, } \\
\text { the court shall continue the trial as necessary but } \\
\text { for no more than } 3 \text { months if the defendant or } \\
\text { defendant's attorney states under oath that the trial } \\
\text { cannot proceed because a material witness is not } \\
\text { present, along with other factors. } \\
\text { As of the date of the initial publication of this Survey, } \\
2021 \text {, there is a bill engrossed in the Minnesota } \\
\text { legislature that would repeal M.S.A. 504B.341. } \\
\text { NINETY-SECOND SESSION H. F. No. } 1077 \text {. } \\
\text { See also Minn. Stat. Ann. } \S 504 B .421 \text { : Hearings } \\
\text { (which governs continuance of hearings in actions } \\
\text { brought by a tenant against a landlord). } \\
\text { Minn. Stat. Ann. } \S 504 B .291(1) \text { (a), providing a right } \\
\text { of redemption. Under this law, the tenant may, at any } \\
\text { time before possession has been delivered, redeem } \\
\text { the tenancy and be restored to possession by } \\
\text { paying to the landlord or bringing to court the } \\
\text { amount of the rent that is in arrears, with interest, }\end{array}$ & $\begin{array}{l}\text { Minn. Stat. Ann. } \$ 546.08 \text {. Continuance } \\
\text { A motion to postpone a trial for the absence of evidence can } \\
\text { only be made upon affidavit, stating the evidence expected to be } \\
\text { obtained, the reasons for its absence and for expecting that it can } \\
\text { be procured, and showing its materiality and that due diligence } \\
\text { has been used to procure it; and if the adverse party thereupon } \\
\text { admits that such evidence would be given and that it be } \\
\text { considered as actually given at the trial, or offered and rejected } \\
\text { as improper, the trial shall not be postponed. } \\
\text { Minn. Stat. Ann. } \S 546.08 \text { : stating any postponement of trial } \\
\text { requested must be accompanied by an affidavit which states the } \\
\text { evidence expected to be obtained. } \\
\text { "Generally, whether to stay a proceeding is discretionary with } \\
\text { the district court, its decision on the issue will not be altered on } \\
\text { appeal absent an abuse of that discretion, and the test for } \\
\text { whether an abuse of discretion occurs is 'whether a denial of a } \\
\text { continuance would prejudice the outcome of the trial."” } \\
\text { Real Est. Equity Strategies, LLC } v . \text { Jones, } 720 \text { N.W.2d } 352,358 \\
\text { (Minn. Ct. App. 2006) (quoting Lanzo } v . F \text { \& } D \text { Motor Works, } \\
396 \text { N.W.2d } 631,635 \text { (Minn. Ct. App. 1986)). } \\
\text { "The granting of a continuance is within the trial court's } \\
\text { discretion, however, and will not be reversed absent a clear } \\
\text { abuse of discretion. The test for abuse of discretion is whether a } \\
\text { denial of a continuance would prejudice the outcome of the } \\
\text { trial." } \\
\text { Lanzo v. F \& D Motor Works, } 396 \text { N.W.2d } 631,635 \text { (Minn. Ct. } \\
\text { App. } 1986 \text { ) (citing cases). }\end{array}$ \\
\hline
\end{tabular}




\begin{tabular}{|c|c|}
\hline & $\begin{array}{l}\text { costs of the action and an attorney's fee not to } \\
\text { exceed } \$ 5 \text {, and by performing any other covenants of } \\
\text { the lease. If the tenant is unable to pay the interest and } \\
\text { costs, the court may provide an additional seven days } \\
\text { by using its authority under } \S 504 B .345 \text {. } \\
\text { Minn. Stat. Ann. } \S 504 B .345 \text {. Subdiv. } 2 \text {. Expedited } \\
\text { writ: } \\
\text { If the court enters judgment for the plaintiff in an } \\
\text { action brought under section } 504 B .291 \text { as required by } \\
\text { section } 609.5317 \text {, subdivision } 1 \text {, the court may not } \\
\text { stay issuance of the writ of recovery of premises and } \\
\text { order to vacate unless the court makes written } \\
\text { findings specifying the extraordinary and exigent } \\
\text { circumstances that warrant staying the writ for a } \\
\text { reasonable period, not to exceed seven days. }\end{array}$ \\
\hline Mississippi & $\begin{array}{l}\text { Mississippi's landlord-tenant laws can be found at } \\
\S 89-8-1 \text { et seq., and contain provisions for } \\
\text { adjournments. } \\
\text { Miss. Code Ann. } \S 89-7-39 \text {. Adjournments, subpoenas } \\
\text { and attachments; hearings for evictions } \\
\text { The court may, at the request of either party, adjourn } \\
\text { the hearing from time to time, a single adjournment } \\
\text { not to exceed ten (10) days, except by consent, and } \\
\text { may issue subpoenas and attachments to compel the } \\
\text { attendance of witnesses. However, in hearings for } \\
\text { eviction, no adjournment shall extend the entire } \\
\text { hearing beyond forty-five (45) days from the date } \\
\text { the eviction action was filed. }\end{array}$ \\
\hline
\end{tabular}




\begin{tabular}{|c|c|c|}
\hline & $\begin{array}{l}\text { As amended in } 2019 \text {, Mississippi law permits a tenant } \\
\text { to redeem the property after judgment but before the } \\
\text { warrant is issued by paying in full all past due rent, } \\
\text { late fees and costs. The law also permits the tenant to } \\
\text { request the execution of the warrant be stayed for up } \\
\text { to three days upon a showing of good cause. } \\
\text { See Miss. Code. Ann. } § 89-7-45 \text {. When warrant for } \\
\text { removal may issue in cases of nonpayment of rent. } \\
\text { If a judgment of eviction is founded solely upon the } \\
\text { nonpayment of rent and, at the time of the request } \\
\text { for the warrant for removal the full and complete } \\
\text { amount of rent due, including any late fees as } \\
\text { provided in the rental agreement that have accrued as } \\
\text { of the date of judgment, and the costs of the } \\
\text { proceedings, have been paid to the person entitled } \\
\text { to the rent, the magistrate shall not issue a warrant } \\
\text { for removal. } \\
\text { If the rent, late fees and costs have not been paid in } \\
\text { full at the time of the request for the warrant for } \\
\text { removal, the magistrate must immediately issue the } \\
\text { warrant for removal unless the judge determines } \\
\text { that, for good cause shown, a stay not to exceed } \\
\text { three (3) days would best serve the interests of } \\
\text { justice and equity. If it is shown that a stay is likely } \\
\text { to result in material injury to the property of the } \\
\text { person entitled to the rent, no stay shall be granted. }\end{array}$ & \\
\hline Missouri & $\begin{array}{l}\text { Missouri's landlord-tenant laws, found at Mo. Ann. } \\
\text { Stat. } \$ 535.010 \text { et seq., do not contain any provisions } \\
\text { regulating continuances in actions for possession. }\end{array}$ & $\begin{array}{l}\text { Mo. Ann. Stat. } § 517.071 \text { Continuation of case, when- } \\
\text { rescheduling } \\
\text { Generally providing that a case may be continued to a certain } \\
\text { date, not exceeding thirty days, when court makes motion, all }\end{array}$ \\
\hline
\end{tabular}




\begin{tabular}{|c|c|c|}
\hline & & $\begin{array}{l}\text { parties can agree, or upon application of any party for good } \\
\text { cause shown. } \\
\text { See Stough v. Bregg, } 506 \text { S.W.3d 400, } 404 \text { (Mo. Ct. App. 2016) } \\
\text { (in an action for possession, the court concluded "there is } \\
\text { nothing in the statute that would have prohibited [the tenants] } \\
\text { from requesting a continuance before the... trial date."). } \\
\text { As of the date of the initial publication of this Survey, there was } \\
\text { legislation pending to amend Mo. Ann. Stat. } \S 517.071 \text { to } \\
\S 517.091 . \text { See } 2021 \text { Missouri Senate Bill No. 281, Missouri } \\
\text { One-Hundredth First General Assembly, First Regular Session. } \\
\text { "“Where a request meets the requirements of section 517.071.1, } \\
\text { the continuance is mandatory, and a circuit court's refusal to } \\
\text { grant the continuance constitutes a misapplication of the law } \\
\text { warranting reversal."” } \\
\text { Darby v. Mason, } 568 \text { S.W.3d 35, 37-38 (Mo. Ct. App. 2019) } \\
\text { (quoting Boehm v. Allen, 524 S.W.3d 542, 544 (Mo. Ct. App. } \\
\text { W.D. 2017)). }\end{array}$ \\
\hline Montana & $\begin{array}{l}\text { Montana's landlord-tenant laws are found at Mont. } \\
\text { Code Ann. } \S 70-24-101 \text { to } \S 70-24-442 \text {, but the } \\
\text { eviction process is governed by its Forcible Entry and } \\
\text { Detainer statutes, found at Mont. Code Ann. } \S 70-27- \\
101 \text { et. seq. } \\
\text { Mont. Code Ann. } \S 70-27-202 \text {. Actions in justice's } \\
\text { court to be tried within } 10 \text { days } \\
\text { (1) Actions filed in justice's court under this chapter } \\
\text { shall be tried within } 10 \text { days after the appearance or } \\
\text { answer date stated in the summons unless the } \\
\text { defendant applying for a continuance shall give an }\end{array}$ & $\begin{array}{l}\text { Mont. Code Ann. } § 25-4-501 \text {. Motion to postpone trial for } \\
\text { absence of testimony } \\
\text { A motion to postpone a trial on grounds of the absence of } \\
\text { evidence shall only be made upon affidavit showing the } \\
\text { materiality of the evidence expected to be obtained and that due } \\
\text { diligence has been used to procure it. }\end{array}$ \\
\hline
\end{tabular}




\begin{tabular}{|c|c|c|}
\hline & $\begin{array}{l}\text { undertaking to the adverse party with good and } \\
\text { sufficient security to be approved by the court, } \\
\text { conditioned for the payment of all damages and rent } \\
\text { that may accrue if judgment be rendered against the } \\
\text { defendant. } \\
\text { (2) The plaintiff and defendant may stipulate to a } \\
\text { continuance of the trial beyond the limit of this } \\
\text { section without the necessity of an undertaking. } \\
\text { Mont. Code Ann. } § 70-27-204 \text {. Amendment of } \\
\text { complaint after trial begins. } \\
\text { (2) No continuance shall be permitted on account of } \\
\text { such amendment unless the defendant by affidavit } \\
\text { filed shows to the satisfaction of the court good } \\
\text { cause therefor. }\end{array}$ & \\
\hline Nebraska & $\begin{array}{l}\text { Nebraska's landlord-tenant laws, found at } \S 76-1401 \\
\text { et seq., provide that one continuance may be granted } \\
\text { for good cause and subsequent continuances may be } \\
\text { granted for extraordinary cause. } \\
\text { Neb. Rev. Stat. } \S 76-1443 \text {. Continuance; when. } \\
\text { The court may grant a continuance for good cause } \\
\text { shown by either party, but no subsequent } \\
\text { continuance shall be granted except by agreement or } \\
\text { unless extraordinary cause be shown to the court. } \\
\text { For any subsequent continuance extending the initial } \\
\text { trial date into the next periodic rental period, the court } \\
\text { may require a tenant to deposit with the clerk of the } \\
\text { court such rental payments as accrue during the } \\
\text { pendency of the suit. }\end{array}$ & $\begin{array}{l}\text { In actions filed in District Court, an application for continuance } \\
\text { must be in writing and supported by an affidavit which contains } \\
\text { factual allegations demonstrating good cause or sufficient reason } \\
\text { necessitating postponement of proceedings. See Neb. Rev. Stat. } \\
\S 25-1148 \text {. Note that most eviction actions are filed in County } \\
\text { Court, which has no similar requirement. } \\
\text { See Kelly v. Frederickson, No. CI00-59, at * } 1 \text { (Neb. Dist. Ct. } \\
\text { Feb. 17, 2001) (“...the court overruled the motion for } \\
\text { continuance because there was "no showing of good cause or } \\
\text { appearance by the [d]efendant..."). }\end{array}$ \\
\hline
\end{tabular}




\begin{tabular}{|c|c|c|}
\hline Nevada & $\begin{array}{l}\text { Nevada's landlord-tenant laws, found at Nev. Rev. } \\
\text { Stat. } \S 118 \text { A.010 et seq., do not contain any general } \\
\text { provisions specifically related to continuances of an } \\
\text { eviction proceeding. Although, Nev. Rev. Stat. } \\
\S 118 \text { A. } 490 \text { requires tenant to deposit rent to court } \\
\text { if "judgment is delayed for any reason" - implying } \\
\text { continuances would be permitted. } \\
\text { Nevada law does provide seniors and people with } \\
\text { disabilities a right, in "no cause" evictions (non- } \\
\text { renewals), to request an additional } 30 \text { days to move. } \\
\text { Also, Nevada appears to provide tenants a right to } \\
\text { delay the execution of the writ by up to } 10 \text { days. See } \\
\text { Nev. Rev. Stat. } § 70.010 . \\
\text { See also Nev. Rev. Stat. Ann. } \S \text { J CTS RCP Rule 73A } \\
\text { (right to state judgment upon appeal by paying bond). }\end{array}$ & $\begin{array}{l}\text { Nev. Rev. Stat. } \S 16.010 \text {. Motion to postpone trial on ground of } \\
\text { absence of evidence } \\
\text { Generally, the statute provides that a trial may be postponed for } \\
\text { an absence of evidence. However, it appears each court may } \\
\text { adopt its own rule on continuances. See Dist. Ct. R. Civ. P. Rule } \\
\text { 13. Continuances, which allows a continuance to be granted for } \\
\text { good cause. } \\
\text { See also Justice Ct. R. Civ. P. 12. Motions for Continuance: } \\
\text { Contents, Service of Affidavits; Counter-Affidavits; Argument. } \\
\text { (a) No continuance of a trial in a case shall be granted except } \\
\text { for good cause. A motion or stipulation for continuance shall } \\
\text { state the reason therefor and whether or not any previous request } \\
\text { for continuance had been either sought or granted. The motion or } \\
\text { stipulation must certify that the party or parties have been } \\
\text { advised that a motion or stipulation for continuance is to be } \\
\text { submitted on their behalf and must state any objection the parties } \\
\text { may have thereto. } \\
\text { (b) If a continuance of any trial is granted, the parties must } \\
\text { appear before the clerk of the court within } 5 \text { business days and } \\
\text { reset the case, unless the court waives this requirement. Failure } \\
\text { to follow this rule may result in the court setting the trial date. }\end{array}$ \\
\hline New Hampshire & $\begin{array}{l}\text { New Hampshire does not appear to have a landlord- } \\
\text { tenant act. In New Hampshire, eviction actions are } \\
\text { governed by N.H. Rev. Stat. } § 540: 1 \text { et seq., and } \\
\text { provide no specific guidance on continuances in } \\
\text { eviction proceedings. However, it does provide for a } \\
\text { right to request a stay of the execution of the judgment } \\
\text { for up to three months, so long as the tenant pays rent } \\
\text { into the court during this period. }\end{array}$ & $\begin{array}{l}\text { This statute (N.H. Rev. Stat. } \S 540: 13-c) \text { expressly excludes a } \\
\text { discretionary stay where the landlord establishes nonpayment of } \\
\text { rent. } \\
\text { Nashua Hous. Auth. v. Tassie, } 121 \text { N.H. 449, 450, } 431 \text { A.2d 134, } \\
134 \text { (1981). }\end{array}$ \\
\hline
\end{tabular}




\begin{tabular}{|c|c|c|}
\hline & $\begin{array}{l}\text { N.H. Rev. Stat. } \S 540: 13 \text {-c Discretionary Stay } \\
\text { Dependent on Payment of Rent } \\
\text { I. If the defendant defaults, or confesses judgment, or } \\
\text { if on trial the court rules that the landlord has } \\
\text { sustained his complaint, judgment shall be rendered } \\
\text { that the landlord recover possession of the premises } \\
\text { and costs. A writ of possession shall be issued, } \\
\text { provided that, the court may order the tenant shall } \\
\text { not be dispossessed until a date not later than } 3 \\
\text { months from such default, confession of judgment, } \\
\text { or ruling of the court, provided the court decides that } \\
\text { under all the circumstances justice requires such stay, } \\
\text { based on the reasonableness and good faith of the } \\
\text { parties in their respective reports, complaints, } \\
\text { demands, and evidence. In the event of any such stay } \\
\text { of dispossession, the tenant shall pay the landlord } \\
\text { weekly in advance the weekly former rent, or the } \\
\text { proportional weekly part of the former rent if rent was } \\
\text { payable less often than weekly, and on default of any } \\
\text { such advance weekly payment a writ of possession } \\
\text { shall be issued and the sheriff shall evict the tenant as } \\
\text { soon as possible. }\end{array}$ & \\
\hline New Jersey & $\begin{array}{l}\text { New Jersey's landlord-tenant laws, found at } \\
\S 2 \mathrm{~A}: 18-51 \text { et seq., do not govern continuances of the } \\
\text { trial for possession. However, there are three laws } \\
\text { that permit the delay of the execution of the eviction } \\
\text { order: } \\
\text { N.J. Ct. R. 6:6-6. (extra time to move) Permits a } \\
\text { tenant to seek more time to move out, up to seven } \\
\text { days, upon a showing of good reason why they } \\
\text { cannot be out in time. }\end{array}$ & $\begin{array}{l}\text { Evictions take place in Superior Court. Below is the Superior } \\
\text { Court rule on a obtaining a continuance, referred to in New } \\
\text { Jersey as an adjournment. } \\
\text { N.J. Ct. R. 4:36-3. Trial Calendar } \\
\text { (b) Adjournments, Generally. } \\
\text { An initial request for an adjournment for a reasonable period of } \\
\text { time to accommodate a scheduling conflict or the unavailability } \\
\text { of an attorney, a party, or a witness shall be granted if made } \\
\text { timely in accordance with this rule. The request shall be made }\end{array}$ \\
\hline
\end{tabular}




\begin{tabular}{|c|c|c|}
\hline & $\begin{array}{l}\text { N.J. Stat. } \S 2 \text { A:42-10.6. (Hardship Stay) - the court } \\
\text { can grant an additional } 6 \text { months if the tenant can } \\
\text { show they are unable to find another place to live. } \\
\text { Then tenant must agree to pay the rent during the time } \\
\text { the hardship stay is granted. See also Hous. Auth. of } \\
\text { City of Newark v. West, } 69 \text { N.J. 293, 301, } 354 \text { A.2d } \\
65,69 \text { (1976). } \\
\text { N.J. Stat. Ann. } \S 2 \text { A:18-59.1. (Terminal Illness Stay) } \\
\text { A court can grant an additional } 12 \text { months if the tenant } \\
\text { can prove they have a terminal illness, have lived in } \\
\text { the unit for at least } 2 \text { years prior, and is current in rent } \\
\text { payments. } \\
\text { New Jersey law also provides a right to redeem the } \\
\text { property by paying all amounts past due prior to the } \\
\text { entry of final judgment. See N.J. Stat. } \S 2 \text { A:18-55. } \\
\text { See also } 23 \text { A N.J. Prac., Landlord And Tenant Law } \\
\S 43.11 \text { (5th ed.). }\end{array}$ & $\begin{array}{l}\text { in writing stating the reason for the request and that all parties } \\
\text { have consented thereto. The written adjournment request, which } \\
\text { shall be submitted to the civil division manager, shall also } \\
\text { include a proposed trial date, agreed upon by all parties, to occur } \\
\text { as soon as possible after the problem requiring the adjournment } \\
\text { is resolved. If consent cannot be obtained or if a second request } \\
\text { is made, the court shall determine the matter by conference call } \\
\text { with all parties. Requests for adjournment should be made as } \\
\text { soon as the need is known but in no event, absent exceptional } \\
\text { circumstances, shall such request be made later than the } \\
\text { close of business on the Wednesday preceding the Monday of } \\
\text { the trial week. No adjournments shall be granted to } \\
\text { accommodate dispositive motions returnable on or after the } \\
\text { scheduled trial date. } \\
\text { For cases interpreting N.J. Stat. } § 2 \text { A:18-55 (right of } \\
\text { redemption), See Cmty. Realty Mgmt., Inc. for Wrightstown } \\
\text { Arms Apartments } v \text {. Harris, } 155 \text { N.J. } 212 \text { (1998); Hous. Auth. of } \\
\text { Town of Morristown } v \text {. Little, } 135 \text { N.J. } 274 \text { (1994); Hous. Auth. } \\
\text { of City of Wildwood } v \text {. Hayward, } 81 \text { N.J. } 311,316 \text { (1979) } \\
\text { (holding that even upon default, the tenants would have had until } \\
\text { the close of the court day to pay the rent arrearages into court } \\
\text { and have the proceedings dismissed. N.J.S. 2A:18-55.). }\end{array}$ \\
\hline New Mexico & $\begin{array}{l}\text { New Mexico's landlord-tenant laws are titled Owner- } \\
\text { Resident Relations, and can be found at } \S 47-8-1 \text { et } \\
\text { seq., and provide that continuance may be granted for } \\
\text { good cause. } \\
\text { N.M. Stat. Ann. } \S 47-8-43 \text {. Issuance of summons } \\
\text { B. Upon finding of good cause, the court may } \\
\text { continue the date of hearing on the action for } \\
\text { possession for up to seven days from the date of the } \\
\text { initial hearing. }\end{array}$ & \\
\hline
\end{tabular}




\begin{tabular}{|c|c|c|}
\hline & $\begin{array}{l}\text { As of the date of the initial publication of this Survey, } \\
\text { there was proposed legislation that would remove the } \\
\text { seven-day cap. It would add a section (c) that would } \\
\text { require the court to provide the plaintiff with a list of } \\
\text { non-profits who help with rental assistance. See } 2021 \\
\text { New Mexico House Bill No. } 111 \text {, New Mexico Fifty- } \\
\text { Fifth Legislative Session - First Session } 2021 \text {. }\end{array}$ & \\
\hline New York & $\begin{array}{l}\text { New York's landlord-tenant laws can be found at } \\
\S 220 \text { et seq., but eviction proceedings are governed } \\
\text { by the rules for Summary Proceedings to Recover } \\
\text { Possession of Real Property found at } \S 701 \text { et seq. } \\
\text { N.Y. Real Prop. Acts. Law } \S 745 \text { (McKinney) } \\
\text { 1. Where triable issues of fact are raised, they shall be } \\
\text { tried by the court unless, at the time the petition is } \\
\text { noticed to be heard, a party demands a trial by jury, in } \\
\text { which case trial shall be by jury. At the time when } \\
\text { issue is joined the court, at the request of either } \\
\text { party shall adjourn the trial of the issue, not less } \\
\text { than fourteen days, except by consent of all parties. } \\
\text { A party's second or subsequent request for } \\
\text { adjournment shall be granted in the court's sole } \\
\text { discretion. } \\
\text { As of the date of initial publication of this Survey, this } \\
\text { law was under review in a current congressional } \\
\text { session. } 2021 \text { New York Assembly Bill No. } 7570 \text {, } \\
\text { New York Two Hundred Forty-Fourth Legislative } \\
\text { Session. }\end{array}$ & $\begin{array}{l}\text { "...it is well settled that the grant or denial of a motion for an } \\
\text { adjournment for any purpose is a matter resting within the sound } \\
\text { discretion of the trial court." } \\
\text { Matter of Cassini, } 182 \text { A.D.3d 1, 9, } 118 \text { N.Y.S.3d 702, } 707 \\
\text { (N.Y. App. Div. } 2 \text { 2020) (citations omitted, see case for } \\
\text { additional factors). } \\
\text { "[If] a party serves motions with little or no notice as permitted } \\
\text { by CPLR 406, it is only fair and reasonable for the court to } \\
\text { provide an adequate adjournment to allow for a response to } \\
\text { those motions which cannot be disposed of summarily on their } \\
\text { return date." } \\
\text { Goldman v. McCord, } 120 \text { Misc. } 2 \text { d } 754,756,466 \text { N.Y.S.2d 584, } \\
586 \text { (N.Y. Civ. Ct. 1983). } \\
\text { See also CPLR 406: Motions at Special Proceedings. }\end{array}$ \\
\hline
\end{tabular}




\begin{tabular}{|c|c|c|}
\hline & $\begin{array}{l}\S 753 \text { (stay for up to one year upon a showing that the } \\
\text { tenant cannot reasonably find suitable replacement } \\
\text { housing). }\end{array}$ & \\
\hline North Carolina & $\begin{array}{l}\text { North Carolina's landlord-tenant laws, found at } \S 42-1 \\
\text { et seq., do not include any provisions governing } \\
\text { continuances of eviction matters tried before a } \\
\text { magistrate. However, it appears that on appeal of a } \\
\text { ruling by a magistrate, the matter is retried in the } \\
\text { district court, wherein certain rules governing } \\
\text { continuances apply: } \\
\text { N.C. Gen. Stat. Ann. § 42-34. Generally: } \\
\text { (a) implies that a party may request an extension under } \\
\text { Rule } 40 \text { : "if the case has not been previously } \\
\text { continued in district court, the court shall continue the } \\
\text { case for an appropriate period of time if any party } \\
\text { initiates discovery or files a motion...". } \\
\text { Also, subsections (b)-(f) govern the undertaking of an } \\
\text { appeal and a stay on execution of a judgment for } \\
\text { ejection pending an appeal. } \\
\text { Specifically, (b) provides that a tenant may secure a } \\
\text { stay on execution of the order issued by the magistrate } \\
\text { if he or she pays the clerk any rent that accumulates } \\
\text { after the judgment and any undisputed amount of rent } \\
\text { in arrears. Additionally, if the action was for unpaid } \\
\text { rent, the tenant must pay prorated rent for the days } \\
\text { between the day that the judgment was entered and the } \\
\text { next day when rent will be due under the lease. } \\
\text { To avoid paying rent in arrears (but must still pay as it } \\
\text { becomes periodically due), a tenant can appeal as an }\end{array}$ & $\begin{array}{l}\text { N.C. Gen. Stat. Ann. R. Civ. P. § 1A-1, Rule 40. Assignment of } \\
\text { cases for trial; continuances } \\
\text { (b) No continuance shall be granted except upon application to } \\
\text { the court. A continuance may be granted only for good cause } \\
\text { shown and upon such terms and conditions as justice may } \\
\text { require.... } \\
\text { See also Morguard Lodge Apartments, LLC v. Follum, } 268 \text { N.C. } \\
\text { App. } 466,834 \text { S.E.2d } 455 \text { (2019), appeal dismissed, review } \\
\text { denied, } 839 \text { S.E.2d } 349 \text { (N.C. 2020), and review dismissed, } 839 \\
\text { S.E.2d } 843 \text { (N.C. 2020) (citing Rule 40). } \\
\text { In order to stay execution of judgment for landlord in summary } \\
\text { ejectment proceeding entered two days before rent was due, } \\
\text { tenant was not required to either make additional undertaking to } \\
\text { pay prorated rent for days between day that judgment was } \\
\text { entered and next day when rent was due or to file in forma } \\
\text { pauperis affidavit, where tenant obtained stay of execution by } \\
\text { signing undertaking that she would pay to clerk of superior court } \\
\text { amount of contract rent as it became due periodically after } \\
\text { judgment was entered. } \\
\text { Fairchild Properties v. Hall, } 122 \text { N.C. App. } 286,468 \text { S.E.2d } 605 \\
\text { (1996). }\end{array}$ \\
\hline
\end{tabular}




\begin{tabular}{|c|c|c|}
\hline & $\begin{array}{l}\text { indigent under (c). Certain factors automatically } \\
\text { qualify a tenant as indigent. If the tenant does not } \\
\text { meet those factors, he or she can file an Affidavit of } \\
\text { Indigency Form. } \\
\text { Under (f), if the defendant fails to make payment } \\
\text { within } 5 \text { business days of the due date, execution on } \\
\text { the judgment for possession will be entered. }\end{array}$ & \\
\hline North Dakota & $\begin{array}{l}\text { North Dakota's landlord-tenant laws, found at } \S 47- \\
\text { 16-01 et seq., do not contain any provisions } \\
\text { specifically related to continuances. However, North } \\
\text { Dakota law does provide a mechanism for requesting } \\
\text { a stay of the execution of the order upon a showing of } \\
\text { substantial hardship. } \\
\text { N.D. Cent. Code Ann., } § 47-32-04 \text {. Eviction actions } \\
\text { not joinable with other actions-Exception-When } \\
\text { counterclaims only interposable. } \\
\text { ‥Upon a showing by the defendant that immediate } \\
\text { restitution of the premises would work a substantial } \\
\text { hardship on the defendant or the defendant's family, } \\
\text { except in cases in which the eviction judgment is } \\
\text { based in whole or in part on a disturbance of the } \\
\text { peace, the court may stay the special execution for a } \\
\text { reasonable period, not to exceed five days. }\end{array}$ & $\begin{array}{l}\text { N. D. R. Ct. } 6.1 \text { Continuances } \\
\text { (a) Attorney Engaged. A party is entitled to a continuance on the } \\
\text { ground that his attorney is actually engaged in another trial or } \\
\text { hearing, but only for the duration of the particular trial or } \\
\text { hearing in which the attorney is then engaged. } \\
\text { (b) Other Continuances. Motions for continuance shall be } \\
\text { promptly filed as soon as the grounds therefor are known and } \\
\text { will be granted only for good cause shown, either by affidavit or } \\
\text { otherwise. Stipulations for continuance will not be recognized } \\
\text { except for good cause shown. Every continuance granted upon } \\
\text { motion must be to a future date consistent with the docket } \\
\text { currency standards for district courts, except for good cause } \\
\text { shown. }\end{array}$ \\
\hline Ohio & $\begin{array}{l}\text { Ohio's landlord-tenant laws, found at } \S 5321.01 \text { et } \\
\text { seq., do not contain any provisions specifically related } \\
\text { to continuances. } \\
\text { Ohio Rev. Code Ann. } \S 1923.08 \text { Continuance; bond }\end{array}$ & $\begin{array}{l}\text { A continuance is granted at the discretion of the court; the court } \\
\text { considers six factors when determining if a continuance should } \\
\text { be granted. } \\
\text { Mentor Economic Assistance Corp. v. Eichels, } 61 \text { N.E.3d } 670 \\
\text { (Ct. App. Ohio, 11th Dist. 2016). }\end{array}$ \\
\hline
\end{tabular}




\begin{tabular}{|c|c|c|}
\hline & $\begin{array}{l}\text { No continuance in an action under this chapter } \\
\text { shall be granted for a period longer than eight } \\
\text { days, unless the plaintiff applies for the continuance } \\
\text { and the defendant consents to it, or unless the } \\
\text { defendant applies for the continuance and gives a } \\
\text { bond to the plaintiff, with good and sufficient surety, } \\
\text { that is approved by the court and conditioned for the } \\
\text { payment of rent that may accrue, if judgment is } \\
\text { rendered against the defendant. }\end{array}$ & $\begin{array}{l}\text { "The statutes in R.C. Chapter } 1923 \text { permit expedited service of } \\
\text { process, as little as seven days before trial (R.C. } 1923.06(\mathrm{~A}) \text { ) } \\
\text { and limit the defendant to requesting a continuance of no more } \\
\text { than eight days, unless a bond is provided (R.C. 1923.08). Each } \\
\text { of these provisions serves to speed the ultimate resolution of a } \\
\text { forcible entry and detainer action. However, the law also allows } \\
\text { either party to demand a jury trial, which is not consistent with } \\
\text { creating a summary or expedited trial procedure." R.C. } 1923.10 \text {. } \\
T \& R \text { Properties, Inc. v. Wimberly, 2020-Ohio-4279, } 129,158 \\
\text { N.E.3d 137, 150. }\end{array}$ \\
\hline Oklahoma & $\begin{array}{l}\text { Oklahoma's version of the URLTA, } 41 \text { Okl. Stat. } \\
\text { Ann. } \S \S 101 \text { to } 201 \text {, does not govern continuances } \\
\text { (nor eviction proceedings, for that matter). Rather, } \\
\text { Oklahoma's Forcible Entry and Detainer statutes set } \\
\text { forth the process for proceeding in an action for } \\
\text { possession. See Okla. Stat. Civ. Proc. } § 12-1148.1 \text {. } \\
\text { Oklahoma's FED statutes do not specifically govern } \\
\text { the continuance of a trial for possession. However, } \\
\text { the law does provide for an opportunity to stay the } \\
\text { writ pending appeal: } \\
12 \text { Okl. St. Ann. } \S 1148.10 A \text {. F. The plaintiff's, the } \\
\text { agent of the plaintiff's, or the officer's return shall be } \\
\text { as upon other executions. Within two (2) days of the } \\
\text { date of the judgment, the defendant may post } \\
\text { supersedeas bond conditioned as provided by law. } \\
\text { This time limit may be enlarged by a trial judge's } \\
\text { order to not more than seven ( } 7 \text { ) days after the date } \\
\text { of judgment. } \\
12 \text { Okl. St. Ann. } § 1148.10 B \text {. Curing of default--Good } \\
\text { faith claim of failure to provide minimum services }\end{array}$ & $\begin{array}{l}12 \text { Okl. St. Ann. } \S \S 667 \text { and } 668 \text { are Oklahoma's continuance } \\
\text { statutes. Section } 667 \text { allows a continuance for good cause } \\
\text { shown, but only applies if a party or his attorney of record is a } \\
\text { state legislator. Section } 668 \text { applies to a continuance needed due } \\
\text { to the absence of evidence or a witness. } \\
\text { Most Oklahoma cases on continuances apply to criminal cases or } \\
\text { a continuance by a party opposing a motion for summary } \\
\text { judgment. However, outside of those contexts the Oklahoma } \\
\text { Supreme Court has ruled that "The granting of continuance is } \\
\text { within sound discretion of [the] trial court and refusal to grant } \\
\text { continuance does not constitute reversible error unless abuse of } \\
\text { discretion is shown." } \\
\text { Herbert v. Chicago, R.I. \& P.R. Co., } 544 \text { P.2d } 898,900 \text { (1975). }\end{array}$ \\
\hline
\end{tabular}




\begin{tabular}{|c|c|c|}
\hline & $\begin{array}{l}\text { A. A tenant shall be allowed to cure a default in a } \\
\text { forcible entry and detainer action in the following } \\
\text { instance: } \\
\text { The default of the tenant was due to unpaid rent which } \\
\text { was unpaid due to the good faith claim of a tenant that } \\
\text { the landlord failed to provide the minimum services } \\
\text { required by subsection C of Section } 121 \text { of Title } 41 \text { of } \\
\text { the Oklahoma Statutes; provided that written notice of } \\
\text { said claim or actual notice to the landlord's agent for } \\
\text { collecting rent is provided within ten (10) days of } \\
\text { the date that rent became due. } \\
\text { B. In such instance, the order of the court must recite } \\
\text { that the tenant by paying the judgment including court } \\
\text { costs and attorney fees, by cash or cashier's check, } \\
\text { within seventy-two (72) hours can avoid a writ of } \\
\text { execution, cure the breach and remain in the } \\
\text { premises. }\end{array}$ & \\
\hline Oregon & $\begin{array}{l}\text { Oregon's version of the URLTA, Or. Rev. Stat. Ann. } \\
\S \S 90.100 \text { to } 90.450 \text {, does not govern continuances. } \\
\text { Rather, Oregon's Forcible Entry and Wrongful } \\
\text { Detainer governs trial proceedings for an eviction. } \\
\text { Oregon's FED statutes provide: } \\
\text { Or. Rev. Stat. Ann. } \S 105.140 \text {. Continuance } \\
\text { No continuance shall be granted to a defendant for a } \\
\text { longer period than two days unless: } \\
\text { (1) The defendant gives an undertaking to the adverse } \\
\text { party with good and sufficient security, to be } \\
\text { approved by the court, conditioned for the payment of } \\
\text { the rent that may accrue if judgment is rendered } \\
\text { against the defendant; or }\end{array}$ & $\begin{array}{l}\text { Or. R. Civ. P.52. Postponement of cases } \\
\text { A. Postponement. When a cause is set and called for trial, it } \\
\text { shall be tried or dismissed, unless good cause is shown for a } \\
\text { postponement. At its discretion, the court may grant a } \\
\text { postponement, with or without terms, including requiring any } \\
\text { party whose conduct made the postponement necessary to pay } \\
\text { expenses incurred by an opposing party. } \\
\text { Or. Rev. Stat. Ann. } \S 105.111 \text { : State service member } \\
\text { 2) In an action pursuant to ORS } 105.110 \text {, the court may stay the } \\
\text { eviction of the defendant for up to } 90 \text { days if: } \\
\text { (a) The defendant is a state service member; } \\
\text { (b) The agreed-upon rent does not exceed } \$ 1,200 \text { per month; and }\end{array}$ \\
\hline
\end{tabular}




\begin{tabular}{|c|c|c|}
\hline & $\begin{array}{l}\text { (2) In an action for the recovery of the possession of a } \\
\text { dwelling unit to which ORS chapter } 90 \text { applies, the } \\
\text { court orders a defendant to pay rent into court as it } \\
\text { becomes due from the commencement of the action } \\
\text { until entry of a general judgment in the action. If a } \\
\text { defendant fails to pay rent into court as ordered under } \\
\text { this subsection, the action shall be tried forthwith. } \\
\text { As of the date of the initial publication of this Survey, } \\
\text { there is a bill pending that makes provisions to Or. } \\
\text { Rev. Stat. Ann. } \S \S 90.100-90.450 .2021 \text { Oregon } \\
\text { House Bill No. } 3306 \text {, Oregon Eighty-First Legislative } \\
\text { Assembly. }\end{array}$ & $\begin{array}{l}\text { (c) The premises are occupied chiefly for dwelling purposes by } \\
\text { the spouse, children or other dependents of the defendant. } \\
\text { "Generally, the court may grant continuances at its discretion, } \\
\text { with or without terms. ORCP 52A. ... The statute, however, does } \\
\text { not forbid the court from granting a continuance on different } \\
\text { terms with the agreement of the parties." } \\
\text { First Interstate Bank of Oregon, N.A. v. Broadway Mall, Inc., } 68 \\
\text { Or. App. } 587,590,682 \text { P.2d } 821,822 \text { (1984). } \\
\text { "The allusion in the statute to the period during which "rent ** } \\
\text { * may accrue" refers to the time between the granting of a } \\
\text { continuance on a defendant's application therefor and the date } \\
\text { judgment is rendered." } \\
\text { Owen J. Jones \& Son, Inc. v. Gospodinovic, } 46 \text { Or. App. 101, } \\
\text { 106, } 610 \text { P.2d } 1238,1241 \text { (1980). }\end{array}$ \\
\hline Pennsylvania & $\begin{array}{l}\text { In Pennsylvania, eviction proceedings occur in } \\
\text { Magisterial District Court, which has its own court } \\
\text { rules governing continuances and stays. }\end{array}$ & $\begin{array}{l}\text { See Pa. R. Civ. No. } 209 \text { Continuances and Stays. } \\
\text { In general, Rule } 209 \text { states that continuances may be granted } \\
\text { for cause or by agreement and shall be to a specific time and } \\
\text { date. Except for good cause shown, not more than one } \\
\text { continuance shall be granted to each party and shall not extend } \\
\text { the date beyond } 90 \text { days for proceedings commenced pursuant to } \\
\text { Rule } 303 \text { or beyond } 30 \text { days for proceedings commenced } \\
\text { pursuant to Rule } 502 \text {. } \\
\text { See also Pa. R. Civ. P. No. } 216 \text { : Grounds for continuance } \\
\text { See also Philadelphia v. Snitow \& Snitow Profit PA, No. } 51 \text { C.D } \\
2020,2021 \text { WL } 2832918 \text {, at *5 (Pa. Commw. Ct. July } 8,2021 \text { ) } \\
\text { (citing Gillespie v. Com., Dep't of Transp., Bureau of Driver } \\
\text { Licensing, } 886 \text { A.2d } 317,320 \text { (Pa. Commw. Ct. 2005)). } \\
\text { (“.... trial court abused its discretion in denying a continuance } \\
\text { request based solely on the application of an established policy }\end{array}$ \\
\hline
\end{tabular}




\begin{tabular}{|c|c|c|}
\hline & & $\begin{array}{l}\text { requiring agreement between parties regarding continuations } \\
\text { without considering the merits of a specific request or whether } \\
\text { the non-requesting party would be prejudiced by a } \\
\text { continuance."). } \\
\text { City of Philadelphia v. Snitow \& Snitow Profit PA, No. } 51 \text { C.D. } \\
2020,2021 \text { WL } 2832918 \text {, at *4 (Pa. Commw. Ct. July } 8,2021 \text { ) } \\
\text { (general explanation of judicial discretion). } \\
\text { Zarrin v. Jeffries-Baxter, } 2007 \text { PA Super } 354,911,937 \text { A.2d } \\
1126,1129 \text { (2007) (tenant forgetting court date unsatisfactory } \\
\text { excuse for a continuance). } \\
\text { Online Auctions } v \text {. Brimar Enterprises, LLC, No. } 391 \text { WDA } \\
\text { 2014, } 2015 \text { WL } 7573414 \text {, at } * 4 \text { (Pa. Super. Ct. Jan. 20, 2015) } \\
\text { (party illness where they informed opposing counsel, } \\
\text { satisfactory for a continuance). }\end{array}$ \\
\hline Rhode Island & $\begin{array}{l}\text { Rhode Island's landlord-tenant laws can be found at } \\
\S 34-18-1 \text { et seq., and provide that a continuance may } \\
\text { be granted if the tenant files an answer and begins } \\
\text { discovery before the hearing. } \\
34 \text { R.I. Gen. Laws } \S 34-18-35 \text {. Eviction for } \\
\text { nonpayment of rent } \\
\text { (d) If the defendant files his or her answer and } \\
\text { commences discovery prior to the hearing, and it } \\
\text { appears, for good cause shown, that the defendant } \\
\text { will not be able to conduct his or her defense without } \\
\text { the benefit of discovery, the court may continue the } \\
\text { hearing to allow a reasonable time for the completion } \\
\text { of discovery.... }\end{array}$ & \\
\hline
\end{tabular}




\begin{tabular}{|c|c|c|}
\hline & $\begin{array}{l}\text { See also } 34 \text { R.I. Gen. Laws } \S 34-18-47 \text { to } 52 \\
\text { (providing automatic 5-day stay, and may stay } \\
\text { execution during pendency of appeal if pays rent as } \\
\text { accrues). }\end{array}$ & \\
\hline South Carolina & $\begin{array}{l}\text { South Carolina's landlord-tenant laws are found at } \\
\text { S.C. Code } \$ \S 27-40-10 \text { to } 27-40-940 \text {, but eviction } \\
\text { proceedings are governed by its ejectment statutes. } \\
\text { South Carolina's ejection statutes do not include any } \\
\text { provisions pertaining to the continuance of an } \\
\text { ejectment proceeding. However, they provide for an } \\
\text { opportunity for the tenant to stay the execution during } \\
\text { the pendency of an appeal upon payment of a bond. } \\
\text { S.C. Code } \S 27-37-130 \text {. Bond required to stay } \\
\text { ejectment on appeal. } \\
\text { An appeal in an ejectment case will not stay } \\
\text { ejectment unless at the time of appealing the tenant } \\
\text { shall give an appeal bond as in other civil cases for } \\
\text { an amount to be fixed by the magistrate and } \\
\text { conditioned for the payment of all costs and damages } \\
\text { which the landlord may sustain thereby. In the event } \\
\text { the tenant shall fail to file the bond herein required } \\
\text { within five days after service of the notice of appeal } \\
\text { such appeal shall be dismissed by the trial magistrate. }\end{array}$ & $\begin{array}{l}\text { SCRCP 40. General Docket, Trial Rosters, and Call of Cases for } \\
\text { Trial } \\
\text { (i) Continuance } \\
\text { (1) For Cause. As actions are called, counsel may request that } \\
\text { the action be continued. If good and sufficient cause for } \\
\text { continuance is shown, the continuance may be granted by } \\
\text { the court. Ordinarily such continuances shall be only until the } \\
\text { next term of court. Each scheduled calendar week of circuit } \\
\text { court shall constitute a separate term of court. }\end{array}$ \\
\hline South Dakota & $\begin{array}{l}\text { South Dakota's landlord-tenant act is titled Lease of } \\
\text { Real Property and can be found at S.D. Codified Laws } \\
\S 43-32-1 \text { et seq., but the eviction process is conducted } \\
\text { pursuant to its Forcible Entry and Detainer Statutes } \\
\text { found at S.D. Codified Laws } \S 21-16-1 \text { et seq., which } \\
\text { permits continuances of up to fourteen days. }\end{array}$ & $\begin{array}{l}\text { S.D. Codified Laws } \S 15-11-4 \text { : Postponement of trial or hearing: } \\
\text { "When an action or proceeding is called for trial or hearing, or at } \\
\text { any time previous thereto, the court or judge may, upon good } \\
\text { cause shown, direct the trial or hearing to be postponed to }\end{array}$ \\
\hline
\end{tabular}




\begin{tabular}{|c|c|c|}
\hline & $\begin{array}{l}\text { S.D. Codified Laws } \S 21-16-7 \text {. Time for appearance } \\
\text { by defendant } \\
\text { The time for appearance and pleading shall be four } \\
\text { days from the time of service on the defendant or } \\
\text { thirty days after the publication of service under } \S 21 \text { - } \\
\text { 16-6.1, whichever occurs sooner. No adjournment or } \\
\text { continuance shall be made for more than fourteen } \\
\text { days, unless the defendant applying therefor shall } \\
\text { give an undertaking to the plaintiff with good and } \\
\text { sufficient surety to be approved by the court, } \\
\text { conditioned for the payment of the rent that may } \\
\text { accrue, together with costs if judgment be rendered } \\
\text { against the defendant. }\end{array}$ & $\begin{array}{l}\text { another day of the same or next term, or to such time as shall be } \\
\text { just in view of all the circumstances." } \\
\text { In determining good cause, the court considers four factors. } \\
\text { Meadowland Apartments v. Schumacher, } 813 \text { N.W.2d } 618 \text {, (S.D. } \\
2012 \text { ). } \\
\text { "A continuance of up to five days could have been granted to } \\
\text { Mr. Soltesz only if he posted surety to cover the rent due..." } \\
\text { Soltesz v. Rushmore Plaza Civic Ctr., } 863 \text { F. Supp. } 2 \mathrm{~d} 861,882 \\
\text { (D.S.D. 2012). }\end{array}$ \\
\hline Tennessee & $\begin{array}{l}\text { Tennessee's landlord-tenant laws are found at Tenn. } \\
\text { Code Ann. } \S \S 66-28-101 \text { to } 66-28-521 \text {, but the } \\
\text { eviction process is conducted pursuant to its Forcible } \\
\text { Entry and Detainer statutes, which permit a } \\
\text { continuance for up to } 15 \text { days upon a showing of good } \\
\text { reason. } \\
\text { Forcible entry and detainer } \\
\text { Tenn. Code Ann. } \S 29-18-118 \text {. Trial; postponement } \\
\text { The general sessions judge may, at the request of } \\
\text { either party, and on good reason being assigned, } \\
\text { postpone the trial to any time not exceeding fifteen } \\
\text { (15) days. The postponement shall not be for a longer } \\
\text { period of time unless agreed upon by the parties, no } \\
\text { civil court is being conducted, or upon request of the } \\
\text { plaintiff, the party making the application for } \\
\text { postponement paying the costs. }\end{array}$ & \\
\hline
\end{tabular}




\begin{tabular}{|c|c|c|}
\hline Texas & $\begin{array}{l}\text { Texas' Forcible Entry and Detainer statutes, found at } \\
\text { Property Code, Title } 4 \text {. Actions and Remedies, } \\
\text { Chapter 24, Forcible Entry and Detainer, govern the } \\
\text { process for proceeding in an action for possession, but } \\
\text { do not include any provision specifically governing } \\
\text { continuances. }\end{array}$ & $\begin{array}{l}\text { Eviction proceedings for Forcible Entry and Detainer in Texas } \\
\text { take place in Texas Justice Court. Texas Justice Courts have } \\
\text { their own rules of civil procedure and have specific rules of } \\
\text { procedure for evictions. } \\
\text { Tex. R. Civ. P. 503.3. Settings and Notice; Postponing Trial. } \\
\text { (b) Postponing Trial. A party may file a motion requesting that } \\
\text { the trial be postponed. The motion must state why a } \\
\text { postponement is necessary. The judge, for good cause, may } \\
\text { postpone any trial for a reasonable time. } \\
\text { Tex. R. Civ. P. 510.7. Trial. } \\
\text { (c) Limit on Postponement. Trial in an eviction case must not } \\
\text { be postponed for more than } 7 \text { days total unless both parties } \\
\text { agree in writing. } \\
\text { Due to COVID-19, Texas has created a Texas Eviction } \\
\text { Diversion Program that the judge has to inform tenants about at } \\
\text { a } 510.7 \text { trial. } \\
\text { See Forty-Second Emergency Ord. Regarding COVID-19 State } \\
\text { of Disaster, No. 21-9118, 2021 WL } 4436908 \text {, at *2 (Tex. Sept. } \\
21,2021 \text { ). }\end{array}$ \\
\hline Utah & $\begin{array}{l}\text { Utah Code Ann. } \S \S 78 b-6-801 \text { to } 78 b-6-816 \text { Forcible } \\
\text { Entry and Detainer, governs eviction hearings in Utah. } \\
\text { It does not include any provisions governing a } \\
\text { continuance of a trial on an action for possession. } \\
\\
\text { In Utah, unlike in many states, the trial date is not } \\
\text { immediately set (except in cases involving alleged } \\
\text { criminal activity. See } § 78-B-6-810(3) \text { ). Instead, the } \\
\text { tenant is required to file an answer within three days }\end{array}$ & $\begin{array}{l}\text { Utah R. Civ. P. 40. Scheduling and Postponing a Trial } \\
\text { (b) Postponement. The court may postpone a trial for good } \\
\text { cause upon such terms as are just, including the payment of } \\
\text { costs. } \\
\text { See Brown v. Glover, } 16 \text { P.3d 540, 548-49 (2000) (“'Trial courts } \\
\text { have substantial discretion in deciding whether to grant } \\
\text { continuances,' (and their decision will not be overturned unless }\end{array}$ \\
\hline
\end{tabular}




\begin{tabular}{|c|c|c|}
\hline & $\begin{array}{l}\text { of being served. If they fail to file an answer within } \\
\text { three days, a default judgment will be entered in favor } \\
\text { of the landlord and the landlord can immediately } \\
\text { request an Order of Restitution. If they answer, a } \\
\text { hearing will be held within } 10 \text { days to determine } \\
\text { whether further hearing is required, and if so, whether } \\
\text { the tenant should be permitted to remain in the } \\
\text { premises in the interim; the matter can also be tried on } \\
\text { the merits at that initial hearing. } \\
\text { Enforcement of an order of restitution may be stayed } \\
\text { if the tenant requests a hearing to contest the manner } \\
\text { of the enforcement of the order and deposits a bond } \\
\text { with the court. See Utah Code Ann. } \S 78 \mathrm{~B}-6-812 \text {. }\end{array}$ & $\begin{array}{l}\text { that discretion has been clearly abused.”) (quoting Christenson } \\
\text { v. Jewkes, } 761 \text { P.2d 1375, } 1377 \text { (Utah 1988), citing State v. } \\
\text { Cabututan, } 861 \text { P.2d 408, } 413 \text { (Utah 1993)). }\end{array}$ \\
\hline Vermont & $\begin{array}{l}\text { Vermont's landlord-tenant laws are found at } 9 \mathrm{Vt} \text {. } \\
\text { Stat. Ann. Part } 7 \text {, but its eviction proceedings are } \\
\text { governed by either } 12 \mathrm{Vt} \text {. Stat. Ann. } \$ 4851 \text { et seq. } \\
\text { (Superior Court Ejectment), or } 12 \mathrm{Vt} \text {. Stat. Ann. } \\
\S 4911 \text { et seq. (Entry or Detainer). Neither provide } \\
\text { any provisions governing the continuance of an } \\
\text { eviction proceeding. }\end{array}$ & $\begin{array}{l}\text { Vt. R. Civ. P. 40: RULE 40. CALENDAR; ASSIGNMENT; } \\
\text { CONTINUANCES; DISQUALIFICATION } \\
\text { (c) Continuances. } \\
\text { (1) An action that is among the first twenty cases assigned for } \\
\text { trial on a trial list issued under paragraph (a)(2) of this rule, or an } \\
\text { action that has been specially assigned for trial, may be } \\
\text { continued by agreement of the parties only (A) upon notice to } \\
\text { the clerk } 24 \text { hours before the time set for trial and (B) if the } \\
\text { assigned trial date is less than one year from the date of entry of } \\
\text { the action. If so continued, an action shall thereafter be placed on } \\
\text { a trial list or specially assigned only upon motion and a showing } \\
\text { that the parties are, or reasonably can be, ready for trial. An } \\
\text { action listed on a trial list that is not among the first twenty cases } \\
\text { assigned for trial may be continued at any time by agreement of } \\
\text { the parties, subject to the provisions of Rule } 41 \text { (b)( } 1 \text { ). } \\
\text { (2) A motion for continuance of an action shall be made not later } \\
\text { than the opening of the court on the second day of the term in } \\
\text { which the action is in order for trial; but if the cause or ground of }\end{array}$ \\
\hline
\end{tabular}




\begin{tabular}{|c|c|c|}
\hline & & $\begin{array}{l}\text { the motion is not then known, the motion may be made as soon } \\
\text { as practicable after the cause or ground becomes known. } \\
\text { Ordinarily, the only grounds for continuance after the second } \\
\text { day of the term will be the sickness of counsel or parties, the } \\
\text { unavoidable absence of a material witness or evidence, or the } \\
\text { rulings of the Administrative Judge as to conflicting } \\
\text { appointments of trial attorneys. } \\
\text { (3) The entry "continued" shall carry with it an enlargement of } \\
\text { all former orders not complied with, executed, or expressly } \\
\text { discharged. The court may continue the action on such } \\
\text { conditions as to costs and other matters as may be fair and } \\
\text { equitable. } \\
\text { See also Kokoletsos v. Frank Babcock \& Son, Inc., 149 Vt. 33, } \\
\text { 35, 538 A.2d 178, 179 (1987). ("It is well settled that the } \\
\text { 'granting of a continuance by the trial court is a matter of } \\
\text { discretion."' (quoting In re R.S., 143 Vt. 565, 570, } 469 \text { A.2d } \\
751,754 \text { (1983)). "Further, the trial court's 'ruling must be } \\
\text { upheld unless that discretion is exercised upon grounds clearly } \\
\text { untenable, or to an extent clearly unreasonable."') (quoting } \\
\text { Cartin v. Continental Homes, } 134 \text { Vt. 362, 365, 360 A.2d 96, } 99 \\
\text { (1976)). }\end{array}$ \\
\hline Virginia & $\begin{array}{l}\text { Virginia's landlord-tenant laws can be found at } \\
\S 55.1-1200 \text { et seq., and provide that a continuance } \\
\text { may be granted if the tenant pays rent into the court or } \\
\text { asserts a good faith defense to the claim. } \\
\text { Va. Code Ann. } \S 55.1-1242 \text {. Rent escrow required for } \\
\text { continuance in tenant's case } \\
\text { A. Where a landlord has filed an unlawful detainer } \\
\text { action seeking possession of the premises as provided } \\
\text { by this chapter and the tenant seeks to obtain a }\end{array}$ & $\begin{array}{l}\text { Va. Code Ann. } \$ 44-209 \text { : Closure of United States government; } \\
\text { civil relief for furloughed employees and contractors } \\
\text { B. Notwithstanding any provision of law to the contrary, any } \\
\text { tenant as defined in } \S 55.1-1200 \text { who is a defendant in an } \\
\text { unlawful detainer for nonpayment of rent pursuant to } \S 55.1- \\
1245 \text { for rent due after the commencement of a closure of the } \\
\text { United States government seeking a judgment for the payment of } \\
\text { money or possession of the premises shall be granted a } 60 \text {-day } \\
\text { continuance of such unlawful detainer action from the initial } \\
\text { court date if the tenant appears on such court date and provides } \\
\text { written proof that he was furloughed or otherwise was or is not }\end{array}$ \\
\hline
\end{tabular}




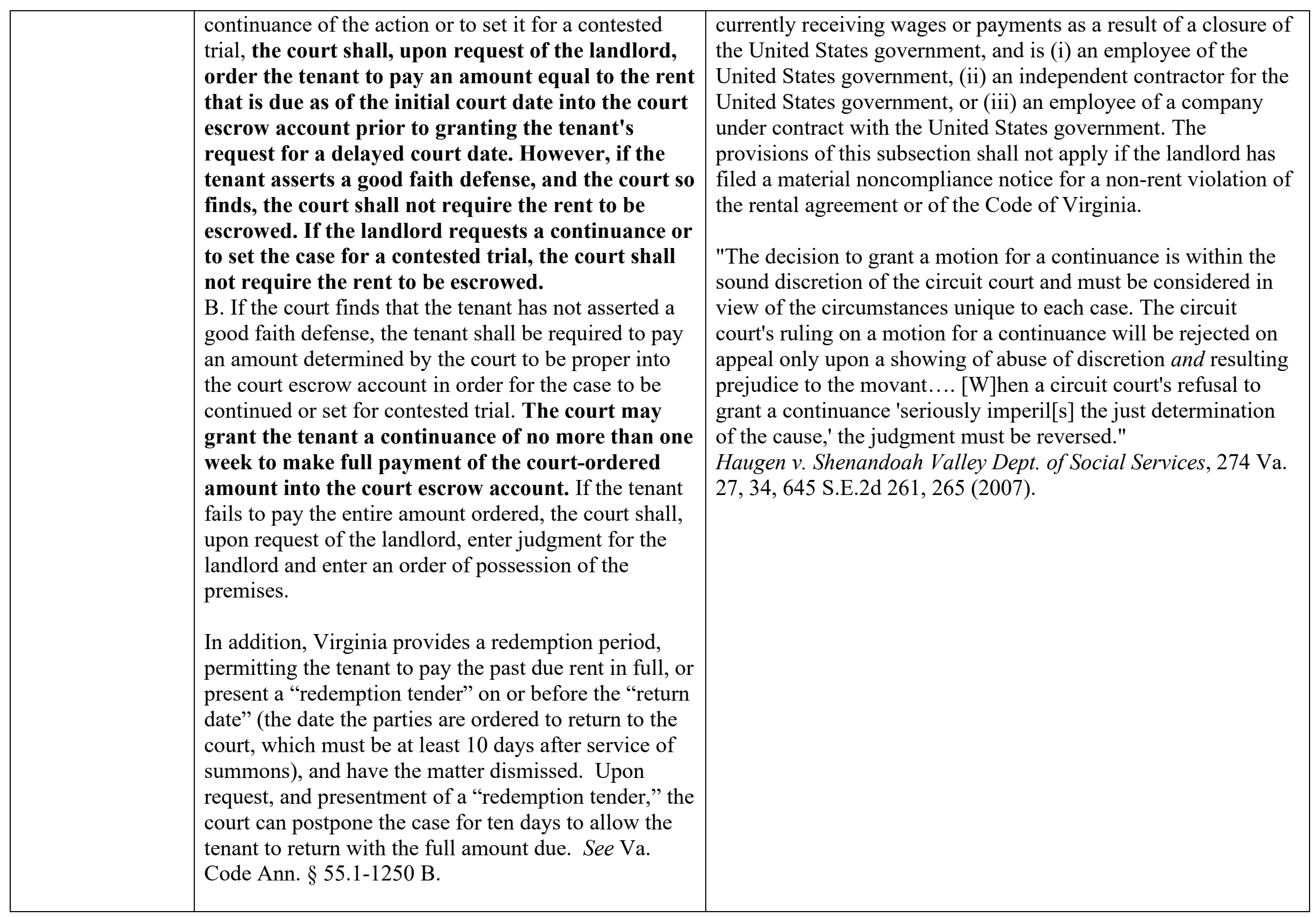




\begin{tabular}{|c|c|c|}
\hline Washington & $\begin{array}{l}\text { Washington's landlord-tenant act, found at } \\
\text { § } 59.18 .010 \text { et seq., does not contain a provision } \\
\text { regulating the continuance of a trial on an action for } \\
\text { possession. } \\
\text { However, Washington law does provide tenants a } \\
\text { right to redemption. See Wash. Rev. Code Ann. } \\
\text { § } 59.18 .410 \text {. Forcible Entry or detainer actions- } \\
\text { Notice of default-Writ of restitution-Judgment- } \\
\text { Execution } \\
\text { (2)... Before entry of a judgment or until five court } \\
\text { days have expired after entry of the judgment, the } \\
\text { tenant or any subtenant, or any mortgagee of the term, } \\
\text { or other party interested in the continuance of the } \\
\text { tenancy, may pay into court or to the landlord the } \\
\text { amount of the rent due, any court costs incurred at the } \\
\text { time of payment, late fees if such fees are due under } \\
\text { the lease and do not exceed seventy-five dollars in } \\
\text { total, and attorneys' fees if awarded, in which event } \\
\text { any judgment entered shall be satisfied and the tenant } \\
\text { restored to his or her tenancy... } \\
\text { In actions where the rent does not exceed } \$ 40 \text { per } \\
\text { month, which likely never occurs in present day, } \\
\text { Washington law has a separate set of statutes that } \\
\text { regulate actions for possession, including a statute that } \\
\text { governs continuances. See Wash. Rev. Code Ann. } \\
\S 59.08 .050 \text { : Continuance (No continuance shall be } \\
\text { granted for a longer period than two days unless the } \\
\text { defendant applying therefor shall give good and } \\
\text { sufficient security, to be approved by the court, } \\
\text { conditioned upon the payment of rent accrued and to } \\
\text { accrue, if judgment be rendered against the } \\
\text { defendant.). }\end{array}$ & $\begin{array}{l}\text { Comments related to the intent of } \S 59-18-410 \text { can be found } \\
\text { within the comments to } \S 59.12 .030 \text { : Unlawful detainer defined: } \\
\text { It is the long-standing practice of the state to make rental } \\
\text { assistance available in many such urgent situations, and it is the } \\
\text { intent of the legislature to provide a payment on the tenant's } \\
\text { behalf to the landlord in certain eviction proceedings to give the } \\
\text { tenant additional time to access resources that allow the tenants } \\
\text { to stay in their home. } \\
\text { Although a motion for continuance is addressed to the discretion } \\
\text { of the trial court, it nevertheless must comply with applicable } \\
\text { rules. } \\
\text { Makoviney v. Svinth, } 21 \text { Wash. App. } 16,584 \text { P. } 2 \text { d } 948 \text { (Div. } 2 \\
\text { 1978). }\end{array}$ \\
\hline
\end{tabular}




\begin{tabular}{|c|c|c|}
\hline West Virginia & $\begin{array}{l}\text { West Virginia's landlord-tenant laws can be found at } \\
\S 37-6-1 \text { et seq., but its eviction process is governed } \\
\text { by its Unlawful Entry and Detainer laws found at } \\
\S 55-3-1 \text { et seq. which provide a right to a continuance } \\
\text { for cause. } \\
\text { W. Va. Code Ann. } \S 55-3 \mathrm{~A}-3 \text {. Proceedings in court; } \\
\text { final order; disposition of abandoned personal } \\
\text { property } \\
\text { (d) Continuances of the hearing provided for in this } \\
\text { section shall be for cause only and the judge or } \\
\text { magistrate shall not grant a continuance to either } \\
\text { party as a matter of right. If a continuance is granted } \\
\text { upon request by a tenant, the tenant shall be required } \\
\text { to pay into court any periodic rent becoming due } \\
\text { during the period of such continuance. }\end{array}$ & $\begin{array}{l}\text { "The granting of a continuance is a matter within the sound } \\
\text { discretion of the trial court, although subject to review, and the } \\
\text { refusal thereof is not ground for reversal unless it is made to } \\
\text { appear that the court abused its discretion, and that its refusal has } \\
\text { worked injury and prejudice to the rights of the party in whose } \\
\text { behalf the motion was made." } \\
\text { State v. Jones, } 84 \text { W.Va. } 85,99 \text { S.E. } 271 \text { (1919). }\end{array}$ \\
\hline Wisconsin & $\begin{array}{l}\text { Wisconsin's landlord-tenant laws are found at Wis. } \\
\text { Stat. Ann. } \S 704.01 \text { et seq., but the procedure for an } \\
\text { action for possession is found at Wis. Stat. Ann. } \\
\S \S 799.40 \text { to } 799-.45 \text {. Small Claims Court - Eviction } \\
\text { Actions. } \\
\text { Wis. Stat. Ann. } \S 799.40 \text {, subsection (4) provides that } \\
\text { the court shall stay an eviction proceeding if the } \\
\text { tenant applies for emergency assistance for families } \\
\text { with needy children, but only if a writ has not been } \\
\text { issued. The stay remains in effect until the tenant's } \\
\text { eligibility for assistance is determined. } \\
\text { Wis. Stat. Ann. } \S 799.44 \text { provides that a writ of } \\
\text { restitution may be stayed for up to } 30 \text { days if the court } \\
\text { determines hardship exists. To obtain the stay, the }\end{array}$ & $\begin{array}{l}\text { See Jay Grenig and Nathan Fishbach, } 4 \text { Wis. Prac., Civil } \\
\text { Procedure Forms 5:12 and 5:13 ( } 3 \mathrm{~d} \text { ed.) (Courts have inherent } \\
\text { power to grant continuances, and are within a court's } \\
\text { discretion.). } \\
\text { In any event, in balancing the needs of the tenant against those } \\
\text { of the landlord, we are satisfied that implicit in the Wis. Stat. } \\
\S 799.40(4) \text { stay is the requirement that the stay will remain in } \\
\text { effect for only a reasonable period of time as determined by the } \\
\text { judge under the circumstances in each individual case. } \\
\text { McQuestion v. Crawford, } 2009 \text { WI App } 35,114,316 \text { Wis. } 2 d \\
494,505,765 \text { N.W.2d } 822,827 \text {. }\end{array}$ \\
\hline
\end{tabular}




\begin{tabular}{|c|c|c|}
\hline & $\begin{array}{l}\text { tenant must pay all rent past due, as well as ongoing } \\
\text { rent. } \\
\text { Wis. Stat. Ann. § } 799.445 \text { provides a means for the } \\
\text { writ to be stayed pending appeal. }\end{array}$ & \\
\hline Wyoming & $\begin{array}{l}\text { All eviction proceedings in Wyoming proceed } \\
\text { pursuant to its Forcible Entry and Detainer statutes at } \\
\S 1-21-1001 \text { et seq. } \\
1977 \text { Wyo. Stat. Ann. } \S 1-21-1002 \text { et seq. governs } \\
\text { Forcible Entry and Detainer and W.S. } 1977 \S 1-21- \\
1201 \text { et seq. governs Residential Real Property. } \\
1977 \text { Wyo. Stat. Ann. } \S 1-21-1007 \text {. Bond on granting } \\
\text { continuance } \\
\text { No continuance shall be granted the defendant for } \\
\text { longer than two (2) days unless he gives a bond to } \\
\text { the adverse party, with good and sufficient surety } \\
\text { approved by the circuit court, conditioned for the } \\
\text { payment of the rent that may accrue and costs if } \\
\text { judgment is rendered against him. }\end{array}$ & $\begin{array}{l}1977 \text { Wyo. Stat. } § 1-9-102 \text {. Continuance for good cause } \\
\text { Any court, for good cause shown may continue any action at any } \\
\text { stage of the proceedings at the cost of the applicant, to be paid as } \\
\text { the court shall direct. } \\
\text { "A trial court may not grant a continuance based upon the mere } \\
\text { whim, request or convenience of counsel in the absence of } \\
\text { substantial factual or legal reason for doing so." } \\
\text { Tomash v. Evans, } 704 \text { P.2d 1296, } 1298 \text { (Wyo. 1985). }\end{array}$ \\
\hline
\end{tabular}

